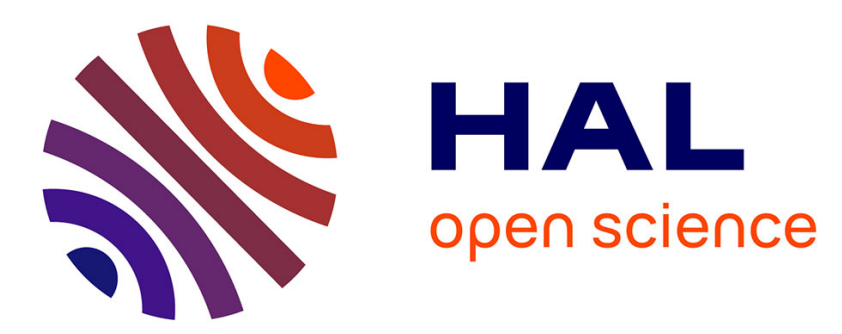

\title{
Deformation mechanisms in a continental rift up to mantle exhumation. Field evidence from the western Betics, Spain
}

Gianluca Frasca, Frédéric Gueydan, Patrick Monie, Jean-Pierre Brun

\section{- To cite this version:}

Gianluca Frasca, Frédéric Gueydan, Patrick Monie, Jean-Pierre Brun. Deformation mechanisms in a continental rift up to mantle exhumation. Field evidence from the western Betics, Spain. Marine and Petroleum Geology, 2016, 76, pp.310-328. 10.1016/j.marpetgeo.2016.04.020 . insu-01310895

\section{HAL Id: insu-01310895 https://hal-insu.archives-ouvertes.fr/insu-01310895}

Submitted on 3 May 2016

HAL is a multi-disciplinary open access archive for the deposit and dissemination of scientific research documents, whether they are published or not. The documents may come from teaching and research institutions in France or abroad, or from public or private research centers.
L'archive ouverte pluridisciplinaire HAL, est destinée au dépôt et à la diffusion de documents scientifiques de niveau recherche, publiés ou non, émanant des établissements d'enseignement et de recherche français ou étrangers, des laboratoires publics ou privés. 


\section{Accepted Manuscript}

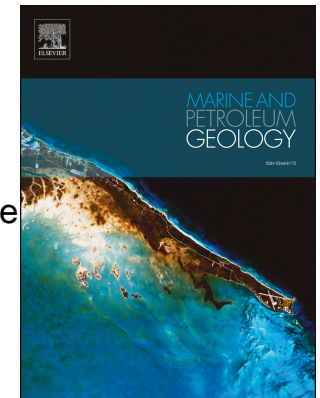

Deformation mechanisms in a continental rift up to mantle exhumation. Field evidence from the western Betics, Spain

Gianluca Frasca, Frédéric Gueydan, Jean-Pierre Brun, Patrick Monié

PII:

S0264-8172(16)30115-5

DOI:

10.1016/j.marpetgeo.2016.04.020

Reference: JMPG 2538

To appear in: Marine and Petroleum Geology

Received Date: 5 June 2015

Revised Date: 13 April 2016

Accepted Date: 20 April 2016

Please cite this article as: Frasca, G., Gueydan, F., Brun, J.-P., Monié, P., Deformation mechanisms in a continental rift up to mantle exhumation. Field evidence from the western Betics, Spain, Marine and Petroleum Geology (2016), doi: 10.1016/j.marpetgeo.2016.04.020.

This is a PDF file of an unedited manuscript that has been accepted for publication. As a service to our customers we are providing this early version of the manuscript. The manuscript will undergo copyediting, typesetting, and review of the resulting proof before it is published in its final form. Please note that during the production process errors may be discovered which could affect the content, and all legal disclaimers that apply to the journal pertain. 


\section{ACCEPTED MANUSCRIPT}

33-25 Ma; Early stages of lithosphere necking

Crust-mantle decoupling, crust heating by exhuming mantle

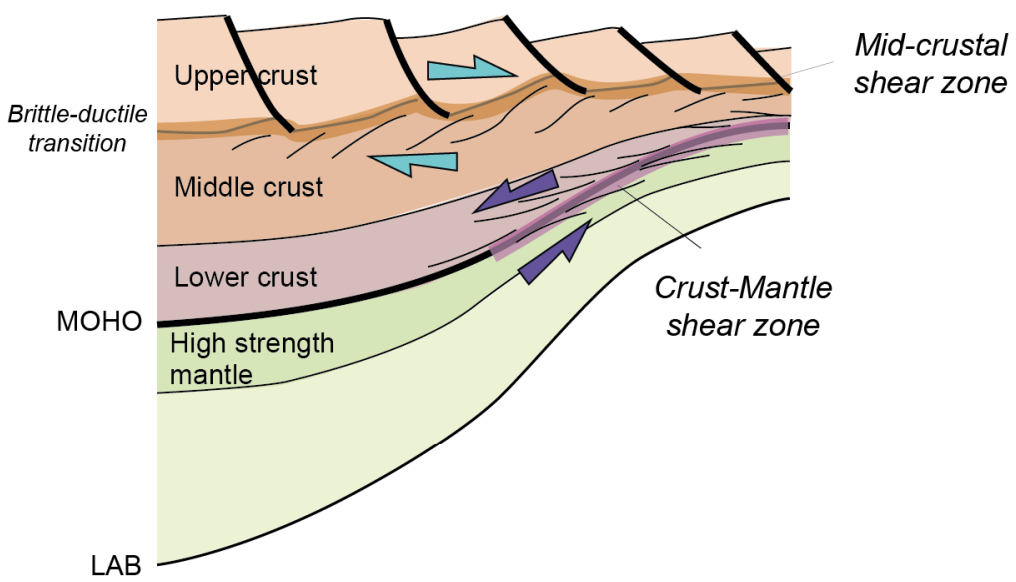

\section{5-22 Ma; Advanced stages of lithosphere necking}

Crust-mantle coupling, localisation (hyper-stretching), onset of cooling

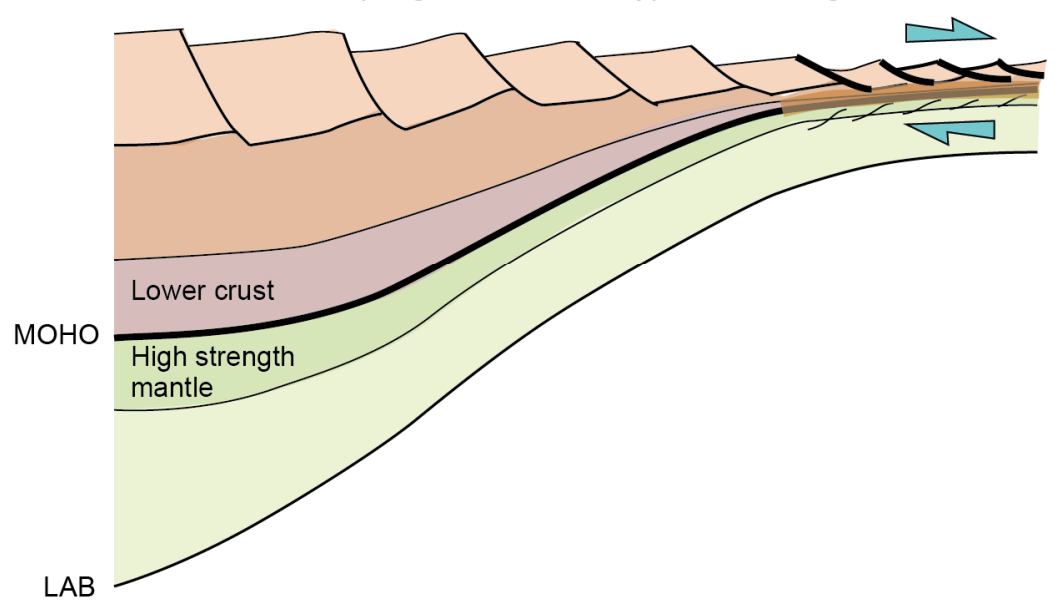

\section{2-20 Ma; Late stages of lithosphere necking}

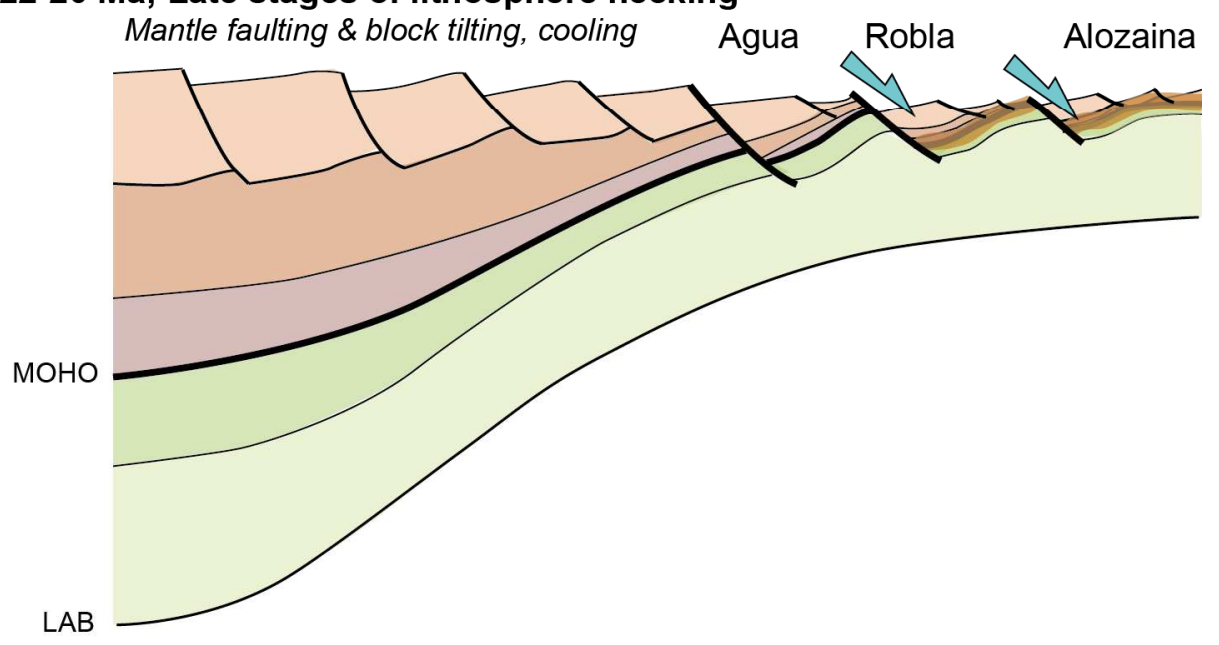




\section{Deformation mechanisms in a continental rift up to mantle exhumation.}

\section{Field evidence from the western Betics, Spain}

3

4

\author{
Gianluca Frasca ${ }^{1,2}$, Frédéric Gueydan ${ }^{2}$, Jean-Pierre Brun ${ }^{1}$, Patrick Monié ${ }^{2}$
}

${ }^{1}$ Géosciences Rennes, Université Rennes 1, UMR 6118 CNRS, Campus de Beaulieu, 35042 Rennes Cedex, France

${ }^{2}$ Géosciences Montpellier, Université Montpellier 2, UMR 5243 CNRS/INSU, Place E. Bataillon, CC60, 34093 Montpellier Cedex, France

*Corresponding author e-mail and telephone number: gianluca.frasca@ univ-rennes1.fr; +33649326203

\section{Abstract}

The identification of the structures and deformation patterns in magma-poor continental rifted margins is essential to characterize the processes of continental lithosphere necking. Brittle faults, often termed mantle detachments, are believed to play an essential role in the rifting processes that lead to mantle exhumation. However, ductile shear zones in the deep crust and mantle are rarely identified and their mechanical role remains to be established. The western Betics (Southern Spain) provides an exceptional exposure of a strongly thinned continental 4 lithosphere, formed in a supra-subduction setting during Oligocene-Lower Miocene. A full 5 section of the entire crust and the upper part of the mantle is investigated. Variations in crustal 
thickness are used to quantify crustal stretching that may reach values larger than $2000 \%$ where the ductile crust almost disappear, defining a stage of hyper-stretching. Opposite senses of shear top-to-W and top-to-E are observed in two extensional shear zones located close to the crust-mantle boundary and along the brittle-ductile transition in the crust, respectively. At locations where the ductile crust almost disappears, concordant top-to-E-NE senses of shear are observed in both upper crust and serpentinized mantle. Late high-angle normal faults with ages of ca. $21 \mathrm{Ma}$ or older $\left({ }^{40} \mathrm{Ar} /{ }^{39} \mathrm{Ar}\right.$ on white mica) crosscut the previously hyper-stretched domain, involving both crust and mantle in tilted blocks. The western Betics exemplifies, probably better than any previous field example, the changes in deformation processes that accommodate the progressive necking of a continental lithosphere. Three successive steps can be identified: i/ a mid-crustal shear zone and a crust-mantle shear zone, acting synchronously but with opposite senses of shear, accommodate ductile crust thinning and ascent of subcontinental mantle; ii/ hyper-stretching localizes in the neck, leading to an almost disappearance of the ductile crust and bringing the upper crust in contact with the subcontinental mantle, each of them with their already acquired opposite senses of shear; and iii/ high-angle normal faulting, cutting through the Moho, with related block tilting, ends the full exhumation of the mantle in the zone of localized stretching. The presence of a high strength sub-Moho mantle is responsible for the change in sense of shear with depth. Whereas mantle exhumation in the western Betics occurred in a backarc setting, this deformation pattern controlled by a high-strength layer at the top of the lithosphere mantle makes it directly comparable to most passive margins whose formation lead to mantle exhumation. This unique field analogue has therefore a strong potential for the seismic interpretation of the so-called "hyper-extended margins". 
51

52

53

54

55

56

57

58

59

60

61

62

63

64

65

66

67

68

69

70

71

72

73 75

74 (Manatschal, 2004; Beltrando et al., 2012; Mohn et al., 2010, and references therein) and in

\section{1/ Introduction}

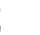

During the last decades, the exhumation of subcontinental lithospheric mantle in rifted margins became a commonly recognized tectonic feature. In the Iberia margin, the case-study for magma-poor continental margin (Boillot et al., 1980; Boillot et al., 1987; Beslier et al., 1990; Whitmarsh and Miles, 1995; Brun and Beslier, 1996), the crustal thickness decreases abruptly in a short horizontal distance $(75 \mathrm{~km}$; Whitmarsh et al., 2001; Péron-Pinvidic and Manatschal, 2009) leading to wide mantle exposures directly to the sea-floor. The sudden extreme thinning of the continental crust has been well imaged through reflection seismics (Péron-Pinvidic et al., 2007; Ranero and Perez-Gussinyé, 2010) and ascribed to polyphased and complex activity of ductile and brittle structures (Manatschal et al., 2001; Péron-Pinvidic et al., 2007).

4

The bulk process responsible for lithosphere thinning up to continental breakup is a "necking" instability that leads to a sharp decrease in crustal thickness and to strong decoupling between upper crust and mantle allowing the mantle to exhume in the rift center (Brun and Beslier, 1996). The final stage of lithosphere thinning, so-called "hyperextension", is then characterized by coupled continental brittle crust and mantle. Faults penetrate into the mantle and "extensional allochtons" of upper crust lie in direct contact with the mantle (Beslier et al., 1993; Manatschal et al., 2001). This final stage of rifting is now well documented worldwide, e.g. in the South Atlantic (Contrucci et al., 2004; Moulin et al., 2005), in the Red Sea (Cochran and Karner, 2007) and in Norway (Osmundsen and Ebbing, 2008), and fossil examples can be observed directly in the field in the obducted margins in the Alps the Pyrenees (Clerc et al., 2012; Clerc and Lagabrielle, 2014). Normal faults and detachment 
76 faults shape this late stage of rift (i.e. "hyperextension") and may obliterate the earlier

77 structures that are responsible for a large part of the lithosphere thinning. It is therefore

78 difficult to obtain a detailed resolution of the first stages of "necking" from seismic data (for a

79 detailed discussion see Reston, 2007). In the other hand, analogue and numerical models

80 reveal that large ductile shear accommodates crust-mantle decoupling and hence controls the

81 process of sub-continental mantle exhumation during lithosphere necking (Brun and Beslier,

82 1996; Gueydan et al., 2008). More generally, many aspects of the relationships between upper

83 crustal faulting and crust-mantle deformation during necking remain poorly understood. As

84 an example, fault displacements observed in seismic lines always remain rather small

85 compared to the overall crustal thinning (Reston, 2007). To reconcile such discrepancies

86 various solutions have already been considered: i) large-scale crustal detachments (Lister et

87 al., 1986; Manatschal et al., 2001; Froitzheim et al., 2006; Mohn et al., 2012), ii) upper crustal

88 brittle faulting accommodated by lower crustal flow (Brun and Beslier, 1996; Ranero and

89 Perez-Gussinyé, 2010; Gueydan and Précigout, 2014) or iii) depth-dependent mechanisms of

90 thinning at different levels in the crust (Davis and Kusznir, 2004; Huismans and Beaumont, 91 2011).

92

To unravel the different stages of necking, a key issue is to characterize deformation

94 of the rifted lithosphere at different levels: subcontinental mantle, deep crust and upper crust.

95 However, sections reaching the deepest levels of a rifted lithosphere are rarely exposed in the

96 field. The large bodies of subcontinental mantle exposed in the westernmost Alboran region,

97 in the western Mediterranean, provide a unique opportunity to study the brittle and ductile

98 deformations that developed during lithosphere necking. In this region, a complete section of

99 the stretched continental crust is associated to the exhumation of the Ronda Peridotites that is,

100 with its three main massifs, the world largest outcrop of subcontinental mantle (Balanyá et al., 
1997; Argles et al., 1999). Major extensional shear zones located at the crust-mantle interface

102 are coeval with the subcontinental mantle exhumation (Afiri et al., 2011; Précigout et al., 2013; Frets et al., 2014; Gueydan et al., 2015). The western Betics is thus a prime location to observe and measure the effects of stretching at different levels of the continental lithosphere

105 (Tubía and Cuevas et al., 1986; Balanyá et al., 1997; Argles et al., 1999; Précigout et al., 106 2013).

In the present paper, we use the outstanding field example of the western Betics to study the patterns of deformation and kinematics that characterize the progressive necking of a continental lithosphere. After a review of the geological and tectonic setting of the Ronda

111 peridotites, we describe i) the structural and geochronological data collected during this study,

112 ii) the major ductile shear zones located in the middle crust and at the crust-mantle transition and iii) the regional gradient of thinning undergone by the crustal units. The discussion is

114 dedicated to the variations of shear sense with depth and to the processes of lithosphere 115 necking in the western Betics.

\section{2/ Geological setting}

121 a non-metamorphosed External Zone (inset of Fig. 1). The Internal-External Zone Boundary

122 (IEZB) separates the Alboran Domain from an external thrust-and-fold belt (e.g. Crespo123 Blanc and Frizon de Lamotte, 2006; Chalouan et al., 2008). Tertiary foreland basins wrap the 124 belt to the North, West and South (Flinch, 1993; Fernández et al., 1998) (shaded in inset of 125 Fig. 1). The External Zone represents the subducting Iberian and Maghrebian margins (pale 
126

127

128

130

131

132

133

134

135

136

137

138

139

140

141

142

143

144

145

146

147

148

grey in inset of Fig. 1) and the Alboran Domain is a portion of the upper plate of the western Mediterranean subducting system (dark grey in inset of Fig. 1) (e.g. Garrido et al., 2011; Platt et al., 2013). A large part of the Alboran Domain stands below sea level in the Alboran Sea basin, whose development is mostly coeval with Miocene shortening in the arcuate External Zone (García-Dueñas et al., 1992; Watts et al., 1993; Balanyá et al., 1997; Comas et al., 1999; Platt et al., 2013).

The metamorphic tectonic units of the Alboran Domain contain in the westernmost sector the Ronda Peridotites. The exhumation mechanism and timing of the Ronda Peridotites have been and are still matter of controversy. Among the proposed mechanisms of mantle rock exhumation are: i) mantle core complex (Doblas and Oyarzun, 1989), ii) crosscutting detachment faults during the extensional collapse of the Betic-Rif chain (Van der Wal and Vissers, 1993; Platt et al., 2003a), iii) transpressional extrusion of a mantle wedge (Tubía et al., 1997; Mazzoli and Martín-Algarra, 2011; Tubía et al., 2013), and iv) inversion during slab rollback of a thinned back-arc lithosphere (Garrido et al., 2011; Hidas et al., 2013; Précigout et al., 2013). Ages of exhumation also strongly vary: i) Paleozoic (Kornprobst, 1976; Ruiz Cruz and Sanz de Galdeano, 2014), ii) Mesozoic (Van Hinsbergen et al., 2014; Vissers et al., 1995) and iii) Oligo-Miocene (Hidas et al., 2013; Précigout et al., 2013).

\section{1/ The Ronda - Beni Bousera subcontinental mantle}

The Ronda Peridotites in southern Spain consist of three main massives, called Bermeja, Alpujata, Carratraca massives (Fig. 1). Several smallest mantle outcrops connect the three larger massives suggesting the original continuity of a single mantle sliver (NavarroVilá and Tubía, 1983; see Didon et al., 1973 for an alternative view). Furthermore, the Ronda 
151 Peridotites in the western Betics were probably originally continuous with the Beni Bousera

152 massif (Sánchez-Gómez et al., 2002) on the Rifean side of the Gibraltar arc (inset in Fig. 1)

153 and then dismembered during the Miocene formation of the Gibraltar arc (Balanyá et al.,

154 1997; Berndt et al., 2015; Chalouan et al., 2008; Frasca et al., 2015). The peridotites display a

155 kilometer-scale petrological zoning with Grt/Sp-peridotites at the top, granular and

156 porphyroclastic Sp-peridotites in the middle and Plag-bearing peridotites at the base (Obata,

157 1980). The Ronda Peridotites sliver is separated from the Alboran continental crustal rocks by

158 two major tectonic contacts: i) the Ronda Peridotites Thrust at the base and ii) the Crust-

159 Mantle extensional shear zone at the top (respectively black and white colors in map and

160 cross-section of Fig. 1) (Tubía et al., 1997; Mazzoli et al., 2013; Précigout et al., 2013;

161 Johanesen and Platt, 2015).

162

The Ronda Peridotites Thrust is a "hot" thrust (Tubía et al., 1997; Esteban et al., 2008)

characterized by a metamorphic sole with: 1/ partial melting in the footwall metamorphic rocks with ages ranging between $22 \mathrm{Ma}$ and $19 \mathrm{Ma}$ (Esteban et al., 2011), and 2/ hightemperature minerals in the basal Mesozoic sediments deformed during Lower Miocene (high-temperature: Mazzoli et al., 2013; deformed Lower Miocene Nava Breccia: Mazzoli and Martín-Algarra, 2011). The Plagioclase tectonites (Fig. 1) usually mark the deformation immediately above the Ronda Peridotites Thrust (Hidas et al., 2013; Précigout et al., 2013).

Conversely, the Crust-Mantle Shear Zone shows structural and petrological evidences

172 of an extensional nature (Tubía and Cuevas, 1986; Balanyá et al., 1997; Argles et al., 1999;

173 Sánchez-Gómez et al., 1999; Précigout et al., 2013). Garnet-spinel mylonites mark the Crust-

174 Mantle Shear Zone with a top-to-SW shearing in the Bermeja massif (Précigout et al., 2013), 175 top-to-E shearing in the Alpujata massif (Tubía and Cuevas, 1986), a variable sense of shear 
176 in the Carratraca area (Tubía et al., 2004), and top-to-NW sense of shear in the Beni Bousera

177 massif (Afiri et al., 2011; Frets et al., 2014). Simultaneously, mantle rocks have recorded a

178 continuous decompression, from the garnet stability field to spinel-peridotite facies (Garrido

179 et al., 2011), related to ductile strain localization at the very top of the mantle units (Précigout

180 et al., 2007; Afiri et al., 2011; Précigout et al., 2013). Gabbros and Cr-rich pyroxenites

181 developed during mantle exhumation (Marchesi et al., 2012; Hidas et al., 2015). Nevertheless,

182 all mantle massives are dominated by spinel lherzolites in which mafic layers are common

183 (Garrido and Bodinier, 1999). The granular plagioclase-peridotites at the base are separated

184 from the overlying spinel tectonites by a "recrystallization front" that marks the asthenosphere

185 boundary (Van der Wal and Vissers, 1996; Lenoir et al., 2001; Soustelle et al., 2009) that is

186 not exposed in the Carratraca massif (Tubía et al., 2004).

2.2/ The western Alboran crust

The western Alboran crustal envelope of the Ronda Peridotites is mainly made of

191 Paleozoic rocks divided in two tectonic units, Alpujarride and Malaguide, which form an

192 Alpine nappe stack most probably related to subduction during the Eocene (e.g. Vergés and

193 Fernández, 2012; Platt et al., 2013). This Alpine nappe stack represents the Alboran crust, on

194 top of the Ronda peridotites, during the Oligo-Miocene evolution (Torres-Roldán, 1979;

195 Tubía et al., 1992). The intrusion of Oligocene tholeitic dykes in both nappes indicates that 196 nappe stacking is pre-Oligocene (Esteban et al., 2013). The Alpujarrides rocks are sometimes 197 divided in granulites, migmatites, gneisses and schists (e.g. Chalouan et al., 2008). Hereafter, 198 following partly previous field observations (Balanyá et al., 1997; Argles et al., 1999), we 199 divide the entire crust -i.e. the Alpujarrides-Malaguide pair- into three lithological groups, 200 namely lower, middle and upper crust (Log of Fig. 1). 
The lower crust is composed by pelitic granulites, characterized by $\mathrm{cm}$-size garnet porphyroclasts interlayered with minor marbles and rare mafic granulites and by migmatites without garnet that often show disrupted and folded leucosomes. A two-step evolution of the high-temperature metamorphism during the Hercynian and the Oligocene has been recently discussed in Gueydan et al. (2015). The middle crust is, from base to top, made of i) sillimanite gneisses, with some strongly stretched migmatitic leucosomes, ii) fibrolite gneisses, without leucosome but still with thin needles of sillimanite, and iii) andalusite gneisses, where andalusite is the only alumino-silicate represented. Quartzites, phyllites and schists with rare andalusite appear close to the transition with the upper crust. The upper crust is composed of the Malaguide rocks made of Paleozoic slates, carbonates, clastic rocks and of scattered Permian terrigenous sediments and Mesozoic carbonates.

Most of the lower and middle crust rocks have amphibolite facies parageneses and partial melting is concentrated in the lower crust. Note that high-pressure low-temperature metamorphism reported in the area (Argles et al., 1999) is related to the pre-rift history - i.e.

217 the Tertiary nappe stacking of Malaguide and Alpujarride units (Balanyá et al., 1997) and 218 probably also the Variscan tectonic history (Ruiz Cruz and Sanz de Galdeano, 2014). The 219 lithological boundaries between lower, middle and upper crustal units roughly reflect the 220 original $650^{\circ} \mathrm{C}$ and $350^{\circ} \mathrm{C}$ isotherms related to the high-temperature metamorphism, as 221 derived by Raman spectrometry on carbonaceous material (Negro et al., 2006) (Log in Fig. 1). 222 The different units are characterized by a fairly continuous temperature increase from upper 223 to lower crustal levels (Argles et al., 1999; Negro et al., 2006). The temperature peak is 224 corroborated also by the evidence of partial melting at the very base of the crust (Platt and 225 Whitehouse, 1999) and by a total reset of low-T chronometers in almost the entire crustal 
section, except in the shallowest levels (Monié et al., 1994; Platt et al., 2003a; Esteban et al., 2004, 2013). At the onset of rifting, the continental geotherm was rather hot and characterized with estimates of Moho temperatures of $\sim 700^{\circ} \mathrm{C}$ (Negro et al., 2006; Gueydan et al. 2015) and $\sim 800^{\circ} \mathrm{C}$ (Argles et al., 1999). Estimates of initial crustal thickness vary from $50 \mathrm{~km}$ (Argles et al., 1999) to 35-40 km (Gueydan et al. 2015). However, such differences do not affect the results of the present study.

In the Alpujarrides, a regional foliation defined by medium-pressure/high-temperature mineral assemblages showing a decrease in pressure (Balanyá et al., 1997; Argles and Platt, 1999; Argles et al., 1999) developed during crustal thinning becoming parallel to the CrustMantle shear zone (Fig. 1, Précigout et al., 2013; Gueydan et al., 2015; Balanyá et al., 1997; Sánchez-Gómez et al., 1999).

\section{3/ Continental rifting in a supra-subduction setting}

The parallelism of foliations in crust and mantle and their development during decompression indicate that the western Alboran domain resulted from the extensional exhumation of a continental lithosphere section (Argles et al., 1999). However, Hercynian, Jurassic and Alpine ages (Montel et al., 2000; Sánchez-Rodriguez and Gebauer, 2000; Sánchez-Navas et al., 2014) suggest that the mantle part of the section likely underwent a rather complex evolution. The present paper does not aim at discussing this long and complex geological evolution of the mantle but only at constraining the deformation pattern that resulted from rifting and related exhumation of the lithospheric mantle. In spite of local complexities, the constant crosscutting relationships reported in the previously published maps (Tubía et al., 1997; Esteban et al., 2008; Mazzoli and Martín-Algarra, 2011; Précigout 
et al. 2013; Frasca et al., 2015) show that the Lower-Miocene Ronda Peridotite Thrust

252 postdates the mantle-crust extensional shear zone. Thinning of the continental lithosphere

253 thinning therefore occured before the Lower Miocene. Because thinning affected the Eocene

254 Malaguide-Alpujarride nappe-stack (Vissers et al., 1995), an Oligocene-early Miocene age, 255 supported by different types of data, can be argued for the rifting.

The exhumation and cooling of the mantle is dated by the garnet pyroxenites seated immediately below the extensional shear zone that separates the mantle from the crust (Sm-

Nd age of 21.5 \pm 1.8 Ma on garnet and clinopyroxene; Zindler et al., 1983) (mean Lu-Hf ages of $25 \pm 1 \mathrm{Ma}$ or $24 \pm 3$ Ma on garnet; Blichert-Toft et al., 1999; Pearson and Nowell, 2004) and by leucosomes stretched within the foliation in partially molten lower crust (U-Th-Pb age of $21.37 \pm 0.87 \mathrm{Ma}$ on monazite; Gueydan et al., 2015) (U-Pb age of $22.0 \pm 0.3 \mathrm{Ma}$ on zircon; Platt et al., 2003b). Note that mantle was exhumed from diamond crystallization conditions (more than $150 \mathrm{~km}$ depth; Pearson et al., 1989; Davies et al., 1993) to garnet stability field (70-90 km) in a previous deformation event, most probably during Jurassic Tethyan rifting 266 (Van der Wal and Vissers, 1993; Afiri et al., 2011; Garrido et al., 2011).

As summarized above, the foliation related to the Crust-Mantle Shear Zone, which

269 affected simultaneously the crust and the upper part of the mantle, developed during 270 decompression under high-temperature conditions. The same sense of shear is recorded in the 271 lower part of the crustal envelope (Balanyá et al., 1997; Argles et al., 1999) and in garnet272 spinel mylonitic zone at the top of the peridotites (Afiri et al., 2011; Balanyá et al., 1997; 273 Précigout et al., 2013; Gueydan et al., 2015). Heating of the lower crust by the exhuming 274 mantle was high enough to induce partial melting in the crustal rocks (Argles et al., 1999; 275 Platt and Whitehouse, 1999). Mantle-related magmatic activity also attests for the hot 
conditions of continental lithosphere during rifting. The crustal emplacement of tholeitic andesites and diorite dyke swarms is likely related to mantle rising (Garrido et al., 2011), as indicated by their location, mostly in the western Betics (Esteban et al., 2013), and their major elements composition (Duggen et al., 2004). The dykes that are abundant in the Malaguide and its Triassic sedimentary cover (Fernández-Fernández et al., 2007) emplaced in the upper and middle crust during E-W stretching (see discussion in Esteban et al., 2013). The ages of $30.2 \pm 0.9 \mathrm{Ma}$ age $\left({ }^{40} \mathrm{Ar} /{ }^{39} \mathrm{Ar}\right.$ on whole rock; Turner et al., 1999) and $33.6 \pm 0.6 \mathrm{Ma}$ (laser ${ }^{40} \mathrm{Ar} /{ }^{39} \mathrm{Ar}$ on a plagioclase from a basalt; Duggen et al., 2004) were recently confirmed by a 33.1 \pm 1.5 Ma age (U/Pb SHRIMP on zircons; Esteban et al., 2013). Younger lower Miocene ages (22-23 Ma: K/Ar age on whole rock; Torres-Roldán et al., 1986; $17.7 \pm 0.6 \mathrm{Ma}{ }^{40} \mathrm{Ar} /{ }^{39} \mathrm{Ar}$ age on whole rock; Turner et al., 1999) are likely related to the thermal cooling of dykes that is controlled by the country rock temperature -i.e. the latest part of the regional hightemperature metamorphic history.

The westward rollback of the Alboran subducting slab is now largely accepted to have shaped the arcuate Betic-Rif belt (Balanyá et al., 2007; Garrido et al., 2011; Platt et al., 2013; 292 Précigout et al., 2013; Johanesen et al., 2014) (Fig. 2). Several large-scale lines of evidence support this interpretation: i) the evolution in the volcanism types (Duggen et al., 2004), ii) the westward shift in the deposition of the foreland basin (Iribarren et al., 2009) and iii) recent tomography imaging of the mantle (Bonnin et al., 2014; Palomeras et al., 2014). Various scenarios have been proposed with significant differences in terms of timing, direction and amount of displacement (Royden, 1993; Lonergan and White, 1997; Gueguen et al., 1998; Wortel and Spakman, 2000; Gutscher et al., 2002; Faccenna et al., 2004; Rosenbaum and Lister, 2004; Vergés and Fernández, 2012). Whatsoever these differences, an overall westward trench displacement is more likely responsible for rifting in the Alboran upper plate 
301 and consequent exhumation of the subcontinental mantle (Garrido et al., 2011; Hidas et al., 2013; Précigout et al., 2013) (Fig. 2a). The geochemical signature of magmatic intrusions in the Ronda Peridotites indicates that they were located in the subduction upper plate (Marchesi et al., 2012) (Fig. 2b).

Rifting of the continental lithosphere and subsequent mantle exhumation thus occurred in a supra-subduction setting during Alboran slab rollback in Oligocene-Lower Miocene. The final thrust emplacement of the Ronda peridotites on top of the Iberian passive margin corresponds to a rift inversion that occurred within the subduction upper plate in lower Miocene (Hidas et al. 2013; Précigout et al., 2013) (Fig. 2c).

\section{4/ Positioning of our study}

Our study focuses on an area of the Western Alboran that displays a complete section of thinned continental lithosphere. In the following, the deformation pattern is described at the crust-mantle contact and in the lower, middle and upper crust. Thus, the geometry and kinematics of rift-related structures are defined and the amount of crustal thinning across the exhumed section of thinned continental lithosphere is estimated. Furthermore, we argue that a relationship exists between the lowermost sedimentary basin and the extensional features described. Finally, the implications of our results for the mechanics of lithosphere necking

321 and non-volcanic passive margin formation are discussed.

Following the estimates of Hidas et al. (2013) and Précigout et al. (2013), the amount

324 of crustal thinning in the western Alboran Domain remained moderate bringing the mantle rocks at mid-crustal levels (10-15 km). Conversely, Argles et al. (1999) and Platt et al. 
326 (2003a) suggest that crustal detachments brought mantle rocks to very shallow levels in the

327 Carratraca area, leaving a strongly attenuated crustal envelope (only few $\mathrm{km}$ thick).

328 Furthermore, the intrusion of gabbros in the Ronda Peridotites during the late stage of mantle

329 thinning confirms that the whole continental lithosphere has been affected by an extreme 330 stretching (Hidas et al., 2015).

We focused our study on the Carratraca region because it displays: i) a complete 333 lithospheric section (Soto and Gervilla, 1991; Argles et al., 1999; Tubía et al., 2004) and ii) an excision of the deepest parts of the crust (Chamón Cobos et al., 1972; Cano Medina and Ruiz Reig, 1990; Del Olmo Sanz, 1990). In addition, the structures related to mantle exhumation are in this region rather well preserved: iii) from reworking during rift inversion (absence of plagioclase tectonites related to hot thrusting) and iv) from the effects of Miocene extension related to the formation of the Alboran Sea basin (Comas et al., 1992).

\section{3/ Geometry, deformation and ages of lithosphere thinning}

\section{1/ Structural map of the Carratraca massives}

The three main types of geological units of the study area are (Fig. 3a): i) mantle rocks

346 (green; dark green highlights the grt-sp mylonites), ii) the crustal envelope (purple, brown and

347 beige) and iii) the Alozaina basin that is filled with terrigenous deposits of Lower Miocene 348 age (Sanz de Galdeano et al., 1993; López-Garrido and Sanz de Galdeano, 1999; Suades and 349 Crespo-Blanc, 2013). Foliation trajectories (Fig. 3a) are drawn from 1406 measurements (see also stereoplots in Fig. S1 of "supplementary material"). The N-S trending cross-section (Fig. 
$3513 \mathrm{~b}$ ) is perpendicular to the main foliation trend and cuts, along $22 \mathrm{~km}$ from the El Chenil

352 region to the El Chorro region, the Carratraca mantle massives, the crustal envelope and the

353 Alozaina basin. The crust-mantle boundary dips northward, while the Ronda Peridotite thrust

354 is generally flat-lying. The two main high-angle normal faults of Cerro Tajo and La Robla dip

355 southward and crosscut the Ronda peridotites and its crustal envelope.

In the crustal envelope, foliations dip northward at variable angles (Fig. 3). The main

358 foliation trend is generally parallel to the condensed metamorphic isograds, from granulite to

359 greenschist facies, easing the identification of lower, middle and upper crust. Significant 360 jumps in P-T conditions occur along the Los Grenadillos fault zone (Fig. 3) that likely acted 361 as an important mid-crustal shear zone (Argles et al., 1999). Approaching the upper crust, the 362 intensity of foliation decreases, and lithological boundaries display more evidence of layer363 parallel brittle shear. Low-angle normal faults are common and show breccias and gouges 364 with subhorizontal striaes.

Foliation trajectories highlight the large-scale 3D geometry of the studied domain with broad anticlines cored by the peridotites massives and synclines defined by upper crustal levels and the Alozaina basin. The Cerro Tajo and La Robla faults are large-scale normal faults (Fig. 3) that bound the peridotite massives to the south and south-east, defining the three studied tilted blocks: Agua, Robla and Alozaina. 
offsets (up to $5 \mathrm{~km}$; Fig. 3b). Both faults show a polyphased kinematic history (Soto and

Gervilla, 1991; Argles et al., 1999; Esteban et al., 2004). A structural and kinematic analysis

of the two faults has been carried out using classical brittle shear criteria (e.g. striae, mineral

fibers, Riedel-type shear faults or deflection of foliations) observable on $10 \mathrm{~m}$-scale fault surfaces. The damage zones of both faults commonly show meter-scale offsets (Figs. $4 \mathrm{~d}$ and 4e). Both faults display similar kinematic patterns with a principal direction of stretching topto-S or E, and a principal direction of shortening top-to-N-NW.

The La Robla fault has been interpreted as a recent normal fault (Insua-Arevalo et al., 2012). Instead, the Cerro Tajo fault has been described with movements top-to-N (Argles et al., 1999; Esteban et al., 2004) or top-to-S with a dextral strike-slip component (Soto and Gervilla, 1991; Crespo-Blanc and Campos, 2001), during Burdigalian to Serravallian. Considering the large normal offset of these faults and their obvious control on the bulk structure of the area, we collected a sample of a hydrothermal tectonic breccia (Fig. 4b) along the Cerro Tajo fault (Fig. 4a) in order to date displacement along these high-angle normal

391 faults. Millimetric white micas are pervasive in the very fine-grained matrix of the tectonic 392 breccia (white arrow in Fig. 4c). White micas that are not observed in the protolith of the breccias define pseudomorphs after garnet (on the left in Fig. 4c) clearly indicating a neoformation of the micas during shearing in presence of fluids (see "supplementary material" 395 and Fig. S3 for further petrographic analysis). ${ }^{40} \mathrm{Ar} /{ }^{39} \mathrm{Ar}$ step heating method on the white 396 micas extracted from the matrix of the tectonic breccia give an age of $21 \pm 0.3 \mathrm{Ma}$ (see age spectrum in Fig. 4f). Details on the method, a table summarizing the data and a complete set of isotopic results are given in the "supplementary material". 
The age of these neo-formed white micas from the tectonic breccia clearly indicates

401

402

403

404

405

406

407

408

409

that at least part of the fault activity is older than what was previously reported. It is rather difficult to directly attribute this age to the extensional or compressional features observed in the field, since the micas were separated from fault rocks. However, the age gives a minimum boundary for the activity of the major fault zone that coincides with the ${ }^{40} \mathrm{Ar} /{ }^{39} \mathrm{Ar}$ age of the micas composing the regional foliation related to the extension, as described above (Monié et al., 1994). On this basis and taking into account previously published data, we consider that a first extensional stage, most probably at ca. 21 Ma or older, with a top-to-S sense of shear in present-day coordinates (see also Soto and Gervilla, 1991) was then followed by a contractional reactivation with a strong component of dextral strike-slip shear during late Burdigalian (Esteban et al., 2004; Frasca et al., 2015).

\section{3/ The Alozaina basin}

The Alozaina Basin (here name as such for sake of simplicity) (Figs. 1 and 3) is a terrigenous Aquitanian to Langhian basin that includes three main groups (Serrano et al., 2007; Suades and Crespo-Blanc, 2013 and references therein). At the base, the CiudadGranada group is Aquitanian (22-20 Ma; dark yellow in Fig. 3). In the middle, La Viñuela group is Burdigalian (20-18 Ma) and at the top the "Neonumidian" olistostrome-type deposits are Burdigalian - Langhian (around 18-15 Ma) (Bourgois, 1978; Martín-Algarra, 1987). A first important feature of the basin is an upward deepening trend associated to a change in sedimentation-type around $20 \mathrm{Ma}$ when clasts of metamorphic rocks of the Alboran Domain and locally peridotites started to be deposited in the basin (Aguado et al., 1990). A second important character of the basin is the important amount of olistostromic deposits that have 
424 been associated to thrusting in previous studies (e.g. Suades and Crespo-Blanc, 2013; Frasca

425 et al., 2015).

Both high-angle normal faults of Cerro Tajo and La Robla (Fig. 3) are likely

contemporaneous to sediment deposition in the Alozaina basin because, first, they display

dip-parallel offsets up to $5 \mathrm{Km}$ and, second, the distribution of sediments is strongly linked to

430 the location of faults. The base of the transgressive cover of the Alboran Domain (dark yellow

431 in Fig. 3a) crops out completely only near Alozaina (Bourgois et al., 1972a, 1972b) while several smaller outcrops are scattered along the unconformity with the Alboran metamorphic rocks (Peyre, 1974; Sanz de Galdeano et al., 1993; Serrano et al., 2007; Alcalá et al., 2014).

The base of the transgressive units is lower Aquitanian, similar to the activity of the La Robla

435 fault inferred from ${ }^{40} \mathrm{Ar} /{ }^{39} \mathrm{Ar}$ dating of fault gouges (Fig. 4). These coeval onsets of sedimentation in the Alozaina Basin and high-angle normal faulting in La Robla and Cerro Tajo provide an important constraint for the tectonic calendar of the area.

\section{4/ Strain and kinematics in crust and mantle}

A regional foliation coeval with medium-pressure/high-temperature metamorphism

443 developed during continental rifting and related crustal thinning whose mean direction is 444 almost parallel to the condensed metamorphic isograds in both ductile crust and mantle. Two 445 types of shear indicators are observed: ductile in mantle and lower/middle crust and brittle446 ductile in middle/upper crust. Figure 5 shows outcrop photographs of the different types of 447 shear criteria used throughout the entire thinned section of the continental lithosphere. In 448 Figure 6, arrows represent the mean senses of ductile shear in the lower crust and mantle 
(violet), and in the middle crust (dark blue). Two opposite senses of ductile shear, top-to-E

450 and top-to-W, are observed that will be discussed in detail below. Brittle/ductile shear (light

451 blue arrows) that are observed in the upper crust and top middle crust can be related either to

452 rifting/thinning or to local later reactivation. The criteria adopted for data selection are also

453 discussed below.

\section{1/ Kinematics of ductile deformation}

a) In the Crust-Mantle shear zone. In the garnet-mylonitic peridotites of the Agua and

Robla blocks, C'-type shear bands often associated with strongly stretched pyroxenite layers give a sense of shear dominantly top-to-W (Fig. 5b and Fig. 6). Stretching lineations are mainly defined by stretched orthopyroxene crystals. Pyroxenites layers that are parallel to the crust-mantle boundary (Fig. 6) are deflected in the vicinity of the Cerro Tajo fault and close to poles in the stereoplots (Fig. S1). In the lower crust, the main foliation is defined by biotite and sillimanite and locally by strongly stretched leucosome lenses. C'-type shear bands with melt injections are abundant. Sigmoidal melt pressure shadows around garnet porphyroclasts and deflection of leucosomes against C'-type shear bands indicate a sense of shear dominantly top-to-W (Fig. 5c). Stretching lineations that are commonly defined by quartz rods and elongated K-feldspar in granulites and migmatites are subhorizontal and trend mainly E-W, almost parallel to lineations in the garnet-mylonitic peridotites. In summary, in the Agua and Robla blocks, the crust-mantle boundary displays a top-to-W sense of shear at the base of the crust and at the top of the mantle (Fig. 6). Few top-to-E senses of shear are observed but only in scattered and discontinuous brittle/ductile low-angle shear zones (Fig. 6). 
b) In the middle crust, two senses of ductile shear are observed: top-to-W in the lower

475 part of the middle crust and top-to-NE in the upper part of the middle crust. ENE to NEtrending stretching lineations are defined by sillimanite needles in the upper part of the middle crust and by still few E-W trending quartz-sillimanite rods in the lower part. Sheath folds are common (Fig. 5f) that could partly explain the scattering in the lineation trend observed. They indicate high to extremely high values of the principal direction of stretching $\left(\lambda_{1}>7.0\right.$; i.e. stretching $>600 \%$ ) in the middle crust rocks. Deflection of foliations along C'-type shear bands, asymmetric boudinage of competent layers and sigma or delta tails around porphyroclasts indicate a top-to-NE sense of shear (Fig. 5e) and, less frequently, a top-to-W or SW sense of shear in the lower part of the middle crust (Fig. 5d). No superposition of the top-to-W and top-to-NE senses of shear has been identified leading Argles et al. (1999) to propose that deformation was co-axial. These two opposite senses of shear, their respective location in the lower and upper parts of the middle crust and the absence of crosscutting relationships suggest their coeval development. Moreover, the top-to-W sense of shear in the and mantle. In the other hand, the top-to-NE sense of shear in the upper part of the middle crust is in continuity with the sense of shear at the transition between brittle and ductile crust 491 (Fig. 6).

\section{2/ Kinematics of brittle/ductile deformation at whole crustal scale}

In the transition between middle and upper crust, shear criteria combine mixed ductile and brittle features. Asymmetric boudinage and C'-type shear bands in andalusite-bearing quartz veins always show a top-to-E or NE sense of brittle/ductile shearing (Fig. $6 \mathrm{~g}$ ). The 
indicate that the observed senses of shear are related to a single deformation event and not to

500 late local reactivations. Moreover, top-to-NE sense of shear in these ductile-brittle shear

501 indicators is related to veins that contain metamorphic minerals (Fig. 6g), indicating that the

502 development of C'-type shear bands and the overall crustal thinning are related to the regional

503 high-temperature event responsible for the main foliation.

In the upper crust, the metamorphic grade becomes very low and the absence of metamorphic mineral renders almost impossible the separation of shear sense indicators related to crustal thinning from those resulting from late reactivation. Widespread low-angle normal faults are interpreted as associated either to crustal thinning during lower Miocene (Argles et al., 1999) or to middle Miocene extensional reactivation of the Alboran domain during the formation of the Alboran basin (García-Dueñas et al., 1992). crustal section (light blue arrows, Fig. 6) and suggest that a late top-to-E sense of brittle shear

514 affected the entire thinned continental crust with reactivation of the previous lithological 515 boundaries (see also Argles et al., 1999).

4.3/ A gradient of ductile crust thinning: hyper-stretching?

Important variations in crustal thickness can be inferred from the geological map and cross-sections (Fig. 3). The Cerro Tajo and La Robla high-angle normal faults divide the thinned continental lithosphere in three tectonic blocks (Agua, Robla and Alozaina; Fig. 6) in which crustal thickness strongly differ. Map-scale crosscutting relationships indicate that

523 variations in crustal thickness, especially in the ductile crust, were acquired before high-angle 
524 normal faulting, during the Oligocene-Lower Miocene rifting. These map-scale relationships

525 also exclude that variations in crustal thickness could be attributed to later tectonic events and

526 in particular to thrusting.

The variations in crustal thickness can be partly related to erosion, but only in the upper crust. A strong thickness decrease is observed in the lower crust between La Agua and

530 La Robla blocks where thickness values are $560 \mathrm{~m}$ and $370 \mathrm{~m}$, respectively). In the Alozaina

531 block the lower crust is entirely absent and the middle crust preserved only in scattered lenses

532 of few tens meters thick and locally found in direct contact with the serpentinized mantle. The

533 middle crust shows a comparable thickness variation, from $1510 \mathrm{~m}$ to $950 \mathrm{~m}$ in average from

534 the Agua to La Robla blocks. The total thickness variation of the ductile crust, from $1970 \mathrm{~m}$

535 to $70 \mathrm{~m}$ from Agua to Alozaina blocks, corresponds to a layer-perpendicular finite strain $536 \lambda_{v}=0.04$ (i.e. $96 \%$ shortening). In plane strain, this would imply a layer-parallel finite strain $537 \lambda_{h}=25.0$ (i.e. a bulk stretching amount of 2400\%), what can be called "hyper-stretching". Such 538 amount of thinning-stretching is entirely related to ductile strain and cannot be simply related 539 to high-angle normal faulting. The strong gradient of layer-perpendicular shortening observed 540 cannot result only from simple shear and is necessarily a combination of layer-parallel shear 541 and layer-perpendicular shortening (i.e. combination of pure shear and simple shear).

\section{4/ Kinematics of brittle/ductile deformation in the hyper-stretched continental lithosphere}

To NE of El Chenil in the Alozaina block, where the crustal section reaches its 546 minimum thickness, a low-angle normal fault (LANF) with top to the E-NE sense of shear 547 (Fig. 6) juxtaposes the upper crustal rocks (Malaguide schists at the top) and serpentinized 548 mantle rocks (Fig. 8a; for detailed map and measurements see Fig. S2). Lower and middle 
crustal rocks are strongly stretched and reduced to meter-scale lenses (Fig. 7). In addition, mylonitic peridotites are not preserved and upper crustal rocks are in direct contact with the spinel-tectonites through the LANF.

The fault zone whose thickness changes along strike from around 10 to $30 \mathrm{~m}$, maintains a characteristic structural zoning (Figs. 8a and 8b). The LANF footwall is marked by a serpentinite zone of 5 to 30 meters thick with a variable degree of brecciation and several outcrops of ophicalcites (Fig. 8c), suggesting the presence of hydrothermal fluids during the LANF activity. In the hanging-wall, the overlying crustal rocks (Fig. 8d) are more pervasively deformed and, in the core, characterized by a gouge with clasts of quartz-veins and gneisses and locally blocks of ophicalcites. In the upper crust close to the fault zone, C'-type shear

560 bands indicate a top-to-E-NE sense of shear (Fig. 8e and steroplots in Fig. S2), as in the middle and upper crust described in sub-section 4.2.

The LANF is cut during the Aquitanian by the high-angle normal fault of La Robla

564 (Figs. 5, 8a and 8b), supporting a rift-related origin. Deposition of breccias and sandstones is 565 locally controlled by C'-type faults in the LANF hanging-wall (Figs. 8a and 8b). The 566 sedimentary rocks deposited at the base of the Alozaina Basin (Ciudad Granada formation, 567 Aquitanian in age) are breccias made of 1-10 cm-large angular clasts, in a sandy yellowish to 568 brownish matrix (Fig. 8f) grading upward into quartz-rich sandstones.

In summary, stretching reached its maximum value in the Alozaina block, leading to the complete omission of the ductile crust. The upper crustal rocks were carried on top of the serpentinized mantle through a LANF with a top-to-E-NE sense of shear, like in the upper 573 crust but opposite to the lower crust/upper mantle. 
5/ Discussion

5.1/ Change in the sense of shear with depth

The ductile deformation that is responsible for the development of foliation and stretching lineations at regional scale is associated to a medium-pressure/high-temperature metamorphism characterized by andalusite and sillimanite in the middle crust and reaching partial melting in the lowermost crust in lower Aquitanian. This extensional deformation i)

584 lead to extreme ductile crust thinning as a result of so-called hyper-stretching in an EW 585 direction and ii) is characterized by a change in the sense of shear with depth, top-to-W in the mantle, lower crust and lower part of the middle crust and top-to-NE in the upper part of the middle crust and in the upper crust.

Top-to-E-NE brittle-ductile shear affected the entire thinned crustal section. The superposition of brittle-ductile deformation on ductile fabrics indicates that the originally ductile crust cooled during thinning and became part of the brittle crust during the extensional process. Consistently, in the hyper-stretched portion of the continental lithosphere, where the ductile crust thickness reaches its lowest value (less than few meters), a concordant top to NE

594 shearing is observed in both strongly thinned crust and serpentinized mantle.

The above conclusions can be summarized graphically with their rheological implications. At the onset of extension (Fig. 9a), the vertical profile of displacement is bellshaped defining: i) a top-to-E sense of shear in the upper crust and top middle crust and ii) a 
top-to-W sense of shear in the lower crust and the sub-continental mantle. In rheological

600 terms, this change in shear sense with depth should be controlled by two strength peaks i) the

601 brittle-ductile transition in the crust and ii) a high strength layer in the sub-Moho mantle that

602 are separated by a weak decoupling layer (i.e. the ductile crust). Upper crust and mantle are

603 thus mechanically decoupled and their respective deformation is accommodated by

604 horizontal flow in the ductile crust. Two main shear zones, the "midcrustal shear zone" and

605 the "crust-mantle shear zone" control the horizontal displacement with opposite sense of shear.

606 After a significant amount of extension and thinning (Fig. 9b) the two shear zones

607 progressively merge in a single one and the upper crust and mantle becomes mechanically

608 coupled, as exemplified by the same top to NE shearing in both crust and mantle in the hyper-

609 stretched portion of the lithosphere.

5.2/ Some remarks about late high-angle normal faulting

614 display large dip-parallel offsets, up to $5 \mathrm{Km}$. During thrusting in late Burdigalian, these

615 faults have undergone minor contractional reactivation with a component of dextral shear

616 (Soto and Gervilla, 1991; Frasca et al., 2015) that did not significantly affected their large

617 normal offset. The two faults that cut trough the crust and mantle controlled block tilting in

618 the Sierra de Agua and Sierra de la Robla. Whereas their prolongation in the Alozaina basin

619 cannot be precisely mapped, few outcrops inside the basin indicate that the sediments are

620 tilted in their hanging-wall (Fig. S2). The Ciudad-Granada group (Serrano et al., 2007) is the

621 first sedimentary formation deposited in the basin (middle and late Aquitanian, 22-20 Ma). It

622 is worth noticing that the ${ }^{40} \mathrm{Ar} /{ }^{39} \mathrm{Ar}$ age that we obtained for the La Robla fault gouge is also

623 Aquitanian - $21 \pm 0.3 \mathrm{Ma}$ - i.e. synchronous with the early sediment deposition in the 
624 Alozaina basin. The sediments are distributed in areas where the ductile crust is missing and

625 their deposition is locally controlled by top-to-ENE C'-type shear bands at the base of the

626 upper crust. The above observations and data indicate that the base of the Alozaina basin is a

627 syn-rift deposit. The Alozaina and Malaga outcrops of the Ciudad Granada group were

628 deposited at depths of less than $200 \mathrm{~m}$, in a shelf environment (Serrano et al., 2007). The

629 shallow environment of the deposition is especially interesting because syn-rift sediments are

630 rarely drilled in modern passive margins (Wilson et al., 2001; Péron-Pinvidic et al., 2007).

631

632

The two faults trend at small angle to the direction of the stretching lineations in the

633 Agua and La Robla blocks. Consequently, these normal faults cannot have developed in the

634 kinematic continuity of the ductile deformation recorded in the tilted blocks. In fact, available

635 paleomagnetic data show that the studied area has undergone dextral rotations up to $60^{\circ}$

636 (Feinberg et al., 1996; Villasante-Marcos et al., 2003) in relation with the formation of the

637 Gibraltar arc during slab rollback (Fig.2). Consequently, the rift that lead to hyper-stretching

638 and mantle exhumation has undergone large rotations during the late stages of its

639 development and during later inversion/thrusting (Platt et al., 1995; Frasca et al., 2015).

640 Whereas it is beyond the scope of the present paper to elaborate on these large-scale tectonic

641 aspects, it is especially interesting to note that these high-angle normal faults, whose

642 development is rather late in the rift history, cut through a brittle mantle layer of more than 5

$643 \mathrm{~km}$ thick. This demonstrates that the extreme thinning of the continental crust in the area had

644 already permitted a fast cooling of the underlying mantle.

645 
The geological observations and the measurements carried out in the Carratraca massif

649 of the Ronda peridotites and its crustal envelope bring new light on the process of lithosphere necking. Whereas the evolution of necking is progressive, it is summarized for convenience in

651 three snapshots, called early, advanced and late stages (Fig. 10).

652

The early stages of necking (Fig. 10a), which are dated between 33 and 25 Ma by the intrusion of the Malaga tholeiites (Turner et al., 1999; Esteban et al., 2013), are characterized by the existence of a high strength subcontinental mantle. A common sense of shear top-to-W in lower crust and uppermost mantle is opposite to the sense of shear top-to-E-NE observed in 657 the middle crust (Fig. 9a). This inversion in the sense of shear with depth strongly constrains 658 the mechanical behavior of the rifted lithosphere. It shows that the ductile middle and lower crust played the role of a decoupling layer (i.e. décollement) between the brittle upper crust and the high strength subcontinental mantle. In rheological terms, it indicates that the mantle 661 strength was higher than the strength of the overlying ductile crust and underlying deeper 662 lithospheric mantle. In addition, strain weakening processes lead to strain localization both at 663 the brittle-ductile transition in the crust and in the uppermost part of the subcontinental mantle 664 (Fig 9a; see discussion in Gueydan et al. 2014). The formation of these two shear zones 665 provides a simple explanation for the observed inversion of shear sense at the boundary 666 between middle and lower crust (Fig 9a and 10a). Analogue and numerical models show that 667 lithosphere necking is accommodated by intense strain localization in the subcontinental 668 mantle (Gueydan and Précigout, 2014) and crust-mantle decoupling (crustal décollement) 669 (Brun and Beslier, 1996; Nagel and Buck, 2004; Gueydan et al., 2008). Moreover, modelling 670 also exemplifies that the necking process corresponds, at lithosphere scale, to a pure shear671 type deformation accommodated by conjugate shear zones with opposite senses of shear, 672 respectively at the base of the brittle crust and in the subcontinental mantle (Brun and Beslier, 
673 1996; Gueydan et al., 2008). The strong mylonitization and thinning of the high-strength

674 mantle (Précigout et al., 2007) allows the deeper and weaker mantle to come into contact with

675 the crust, hence implying a strong heating of the lower crustal levels (Gueydan et al., 2015).

676 This is in agreement with partial melting observed in the lower part of the crust (Platt and

677 Whitehouse, 1999; Whitehouse and Platt, 2003). Such a high geotherm (Negro et al., 2006) is

678 likely related to the supra-subduction setting of rifting in the western Alboran.

679

680

The advanced stages of necking (Fig. 10b), which are dated between 25 and 22 Ma by

681 crystallization and cooling ages within the high-temperature foliation (Esteban et al. 2013; see

682 data compilation in section 2), are characterized by a strong thinning of the ductile crust

683 observed from the Agua to Alozaina blocks. The extremely large gradient of stretching

$684(2400 \%)$ can be qualified of "hyper-stretching". The drastic decrease of the crustal thickness

685 triggers cooling of the attenuated crust and upper part of the lithospheric mantle.

686 Consequently, the initial strength profile with two peaks (Fig. 9a) becomes single peak in the

687 localized zone of stretching (Fig. 9b). In other words, the crust and mantle becomes

688 mechanically coupled and the two major shear zones (i.e. mid-crustal and crust-mantle shear

689 zones) merge into a single, with top to NE shearing between upper crust and serpentinized

690 mantle. Four-layers analogue models of lithosphere extension have consistently shown that

691 the boudinage of the high strength mantle was able to brings into contact the upper part of the

692 crust and the ductile lithospheric mantle with their already acquired opposite senses of shear

693 (Brun and Beslier, 1996).

694

695

The late stages of necking (Fig. 10c), which is dated between 22 and $20 \mathrm{Ma}$ (our

$696{ }^{40} \mathrm{Ar} /{ }^{39} \mathrm{Ar}$ minimum age on the Cerro Tajo fault and Alozaina basin), are characterized by the

697 development of steeply dipping normal faults and related block tilting within this domain of 
698 localized stretching. Cooling thus occurs rapidly in the thinned crust and the underlying mantle, and induces a downward migration of the brittle-ductile transition in the lithospheric mantle. In the western Betics, this event of late brittle deformation is indeed superposed to previous ductile fabrics and is characterized by the formation of tilted blocks of Agua, La Robla and Alozaina, whose formation has been interrupted by thrusting and rift inversion around $20 \mathrm{Ma}$ (Frasca et al., 2015). The syn-rift deposits are coeval with this late stage and mark the onset of subsidence and cooling of the stretched portion of the lithosphere.

Whereas mantle exhumation in the western Betics occurred in a backarc setting, the observed deformation pattern is strongly controlled by the presence of a high-strength layer at the top of the lithosphere mantle. This makes it directly comparable to most passive margin formation that have lead to mantle exhumation and therefore it provides a useful field analogue for the seismic interpretation of the so-called "hyper-extended margins".

\section{4/ Field evidence versus models}

exemplifies the changes in deformation processes that accommodate the progressive necking of a continental lithosphere up to mantle exhumation. The conceptual model shown in figure 10 summarizes our field observations and measurements in three steps that directly result from the three major thermo-mechanical changes that occur during necking of a continental lithosphere: i) the reversal of shear sense with depth is controlled by the initial two-peak strength profile of the lithosphere, ii) extremely strong stretching in the central zone of the lithosphere neck results from the intense strain localization in the subcontinental mantle, and 
iii) the late steep normal faults that crosscut both crust and mantle result from fast cooling in

723 the zone of hyper-stretching.

This progressive deformation pattern that characterizes mantle exhumation in the western Betics (Figs. 11e and f) can be compared with end-member mechanical models in which the bulk deformation is either i) rather symmetrical as a result of an efficient decoupling between the upper crust and lithospheric mantle along a crustal décollement (Figs. $11 \mathrm{a}$ and b, Brun and Beslier, 1996) or ii) starting symmetrical and becoming strongly asymmetrical, controlled by one or more lithosphere-scale detachment(s) (Figs. 11c and d; Mohn et al., 2012). For convenience, only the first stages of lithosphere necking and the last stages of mantle exhumation are represented in Figure 11. The two models differ significantly not only in terms of bulk structural symmetry but also considering the role played by ductile deformation.

In the symmetrical necking model (Figs. 11a and b, Brun and Beslier, 1996) the middle ductile crust (décollement) is sheared top to the rift axis. In the lithospheric mantle, ductile shear is localized below the high strength mantle layer with a sense of shear top away from the rift axis. During increasing extension, the thinning and rupture of the sub-Moho high-strength layer brings into contact the crust and mantle shear zones with their opposite

741 senses of shear. The exhumed mantle only displays the sense of shear top away from rift 742 center. In this process the same pattern of ductile shear affects the two rift margins even if the 743 continental breakup does not occur at the center of the rift zone. In other words, a difference 744 in bulk margin shape (i.e. width and thickness gradient) does not necessarily imply a strong internal asymmetry in terms of structure and kinematics. 
In the asymmetrical hyperextension model (Figs. 11c and d, Mohn et al., 2012), even

748 if rifting starts rather symmetrical, a strong asymmetry characterizes the final structure and of view, this model is characterized by a single sense of shear top-to-detachment hanging wall

753 from the upper crust to the ductile mantle (Lavier and Manatschal, 2006; Whitmarsh et al., 2001). Finally and more importantly, in terms of model prediction, the two conjugate margins in this model, correspond to the hanging-wall and footwall of a lithosphere-scale detachment, respectively. Consequently, they must have strikingly different lithosphere-scale structures and deformation patterns.

The pattern of deformation associated to mantle exhumation in the western Betics (Figs. 11 e and f) has three important outcomes. First, it provides, for the first time, field evidence of a vertical reversal of shear sense as predicted by the laboratory experiments of 762 Brun and Beslier (1996) (Fig. 11a). Second, it shows that crustal layers first underwent a

763 strong thinning, by simultaneous faulting in the upper crust and ductile shear in the middle 764 crust, during which extremely high values of stretching were reached prior to full mantle 765 exhumation. Third, full mantle exhumation was accommodated by newly formed high-angle 766 normal faults, cutting through the strongly thinned middle-lower crust and the underlying 767 brittle mantle, and block tilting. One can expect that, if extension would not have been 768 interrupted by rift inversion, the normal faulting and block tilting would have continued in a 769 core complex exhumation mode of the underlying ductile mantle (Fig. 11f). Mantle detachment faults are thus more likely very late structures of the necking process. 
6/ Conclusions

774

775

Our study that links field geology and geochronology leads to the following conclusions:

776

1/ The western Betics presents an exceptional exposure of a hyper-stretched continental

lithosphere section, which includes the world largest subcontinental mantle massif (Ronda

Peridotites), exhumed during the Oligocene-Lower Miocene in a back-arc tectonic setting.

780

2/ Variations in crustal thickness in the lithosphere section indicate amounts of stretching that may locally reach values as high as $2400 \%$, defining a stage of hyper-stretching.

783

3/ Ductile deformation associated to lithosphere thinning is marked by opposite senses of shear in the lower crust/subcontinental mantle and in the upper/middle crust, highlighting a mechanical decoupling between the upper crust and the localizing subcontinental mantle. The presence of a high strength sub-Moho mantle is responsible for this change in sense of shear with depth. Whereas mantle exhumation in the western Betics occurred in a backarc setting, this deformation pattern, controlled by a high-strength layer at the top of the lithosphere mantle, makes it directly comparable to most passive margin formation that have lead to mantle exhumation. Therefore, this unique field example has a strong potential for the seismic 792 interpretation of the so-called "hyper-extended margins". 4/ In the course of extension, the ductile crust almost disappeared in the hyper-stretched segment (i.e. lithosphere neck) and the upper crust became mechanically coupled to the underlying serpentinized mantle. 
798 5/ On the above bases, three main steps summarize the lithosphere necking process:

i/ a mid-crustal shear zone and a crust-mantle shear zone that acted synchronously but

800 with opposite senses of shear, accommodated ductile crust thinning and ascent of the 801 subcontinental mantle,

802 ii/ hyper-stretching localized in the lithosphere neck lead to an almost disappearance

803 of the ductile crust and brought the upper crust in contact with the subcontinental mantle, each

804 of them with their already acquired opposite senses of shear;

805

iii/ high-angle normal faulting cutting through the Moho and related block tilting

806 achieved the full exhumation of mantle in the domain of localized stretching.

807

\section{Aknowledgement}

809

This work was funded by the European Union FP7 Marie Curie ITN “TOPOMOD”,

811

contract 264517. Thanks to Alexandre Pichat and Hugo Humbert for help in the field.

812 Constructive reviews by Tony Doré and Geoffroy Mohn helped improve the manuscript.

813

814

815

816 
REFERENCES

818

819 Afiri, A., Gueydan, F., Pitra, P., Essai, A., and Précigout, J. (2011). Oligo-miocene 820 exhumation of the Beni-Bousera peridotite through a lithosphere-scale extensional shear zone. 821 Geodinamica Acta, 24(1):49-60.

822

823 Aguado, R., Feinberg, H., Durand-Delga, M., Martín-Algarra, A., Esteras, M., and Didon, J. 824 (1990). Nuevos datos sobre la edad de las formaciones miocenas transgresivas sobre las 825 Zonas Internas Béticas : la Formación de San Pedro de Alcantara (Provincia de Málaga). Revista de la Sociedad Geológica de España, 3(1-2):79-85.

Alcalá, F. J., F. Guerrera, F. M. Martín-Martín, M., Raffaelli, G., and Serrano F. (2014). Geodynamic implications derived from Numidian-like distal turbidites deposited along the Internal-External Domain Boundary of the Betic Cordillera (S Spain). Terra Nova, 25:119129.

833 Argles, T. and Platt, J. (1999). Stepped fibres in sillimanite-bearing veins: valid shear-sense 834 indicators in high grade rocks?. Journal of Structural Geology, 21(2):153-159.

836 Argles, T., Platt, J., and Waters, D. (1999). Attenuation and excision of a crustal section 837 during extensional exhumation: the Carratraca massif, Betic Cordillera, southern Spain. 838 Journal of the Geological Society, 156(1):149-162.

840 Balanyá, J. C., Crespo-Blanc, A., Díaz-Azpiroz, M., Exósito, I., and Luján, M. (2007). 841 Structural trend line pattern and strain partitioning around the Gibraltar arc accretionary 
842 wedge: Insights as to the mode of orogenic arc building. Tectonics, 26(2):TC2005

843

844 Balanyá, J. C., García-Dueñas, V., Azañón, J. M., and Sánchez-Gómez, M. (1997).

845 Alternating contractional and extensional events in the Alpujarride nappes of the Alboran

846 domain (Betics, Gibraltar arc). Tectonics, 16(2):226-238.

847

848 Beltrando, M., Frasca, G., Compagnoni R. and Vitale Brovarone A. (2012). The Valaisan 849 controversy revisited: Multi-stage folding of Mesozoic hyper-extended margin in the Petit St. 850 Bernard Pass area. Tectonophysics. 579:17-36.

851

852 Berndt, T., Ruiz-Martínez, V. C., Chalouan, A. (2015). New constraints on the evolution of 853 the Gibraltar Arc from palaeomagnetic data of the Ceuta and Beni Bousera peridotites (Rif, 854 northern Africa). Journal of Geodynamics, 84:19-39.

855

856 Beslier, M.-O., Ask, M., and Boillot, G. (1993). Ocean-continent boundary in the Iberia 857 abyssal plain from multichannel seismic data. Tectonophysics, 218(4):383-393.

858

859 Beslier, M.-O., Girardeau, J., and Boillot, G. (1990). Kinematics of peridotite emplacement 860 during north Atlantic continental rifting, Galicia, northwestern Spain. Tectonophysics, 184(3): $861321-343$.

862

863 Blichert-Toft, J., Albarède, F., and Kornprobst, J. (1999). Lu-Hf isotope systematics of garnet 864 pyroxenites from Beni Bousera, Morocco: Implications for basalt origin: Science, 283:1303865 1306. 
Boillot, G., Grimaud, S., Mauffret, A., Mougenot, D. Kornprobst, J., Mergoil, D. J., and

868 Torrent, G. (1980). Ocean continent boundary of the Iberian margin: A serpentinite diapir 869 west of the Galicia Bank. Earth And Planetary Science Letters, 48:23-34.

870

871 Boillot, G., Recq, M, Winterer, E.L., Meyer, A.W., Applegate, J., Baltuck, M., Bergen, J.A.,

872 Comas, M.C., Davies, T.A., Dunham, K., Evans, C.A., Girardeau, J., Goldberg, G., Haggerty,

873 J., Jansa, L.F., Johnson, J.A., Kasahara, J., Loreau, J.P., Luna-Sierra, E., Mollade, M., Ogg, J., 874 Sarti, M., Thurow, J., and Williamson M. (1987). Tectonic Denudation Of The Upper Mantle 875 Along Passive Margin: A Model Based On Drilling Results (Odp Leg 103, Western Galicia 876 Margin, Spain). Tectonophysics, 132:335-342.

877

878 Bonnin, M., Nolet, G., Villaseñor, A., Gallart, J., and Thomas, C. (2014). Multiple-frequency 879 tomography of the upper mantle beneath the African/Iberian collision zone. Geophysical 880 Journal International, 198(3):1458-1473.

881

882 Bourgois, J. (1978). La transversale de Ronda (Cordillères Bétiques, Espagne). Données 883 géologiques pour un modèle d'évolution de l'Arc de Gibraltar. Annales Scientifiques de 884 l’Université de Besançon (France), 30:1-445.

885

886 Bourgois, J., Chauve, P., Lorenz, C., Monnot, J., Peyre, Y., Rigo, E. and Rivière, M. (1972a). 887 La formation d'Alozaina. Série d'âge oligocène et aquitanien transgressive sur le Bétique de 888 Malaga. C. R. Acad. Sci. Paris, 275(D):531-534.

889

890 Bourgois, J., Chauve, P., Magne, J., Monnot, J., Peyre, Y., Rigo, E. and Rivière, M. (1972b). 891 La formation de Las Millanas. Série burdigalienne transgressive, sur les zones internes des 


\section{ACCEPTED MANUSCRIPT}

892

893

894

895

896

897

898

899

900

901

902

903

904

905

906

907

908

909

910

911

912

913 Clerc, C., and Lagabrielle, Y. (2014). Thermal control on the modes of crustal thinning

914 leading to mantle exhumation: Insights from the Cretaceous Pyrenean hot paleomargins.

915 Tectonics, 33(7):1340-1359.

Célérier, B. (2013). FSA: Fault \& Stress Analysis software, version 35.1, http://www.pagesperso-bernard-celerier.univ-montp2.fr/software/dcmt/fsa/fsa.html.

Chalouan, A., Michard, A., El Kadiri, K., Frizon de Lamotte, D., Negro, F., Soto, J., and Saddiqi, O. (2008). The Rif belt. In Michard, A., Saddiqi, O., Chalouan, A., de Lamotte, D.F., editors, Continental Evolution: The Geology of Morocco: Structure, Stratigraphy, and Tectonics of the Africa-Atlantic-Mediterranean Triple Junction. Springer: 203-302.

Chamón Cobos, C., Quinquer Agut, R., Crespo, V., Aguilar, M., and Reyes, J.L. (1972). Sheet Alora, 1052. Geological map scale 1:50000, Instituto Geológico y Minero de España, Madrid. 
917 Clerc, C., Lagabrielle, Y., Neumaier, M., Reynaud, J.Y., de Saint Blanquat, M. (2012).

918 Exhumation of subcontinental mantle rocks: evidence from ultramafic-bearing clastic deposits 919 nearby the Lherz peridotite body, French Pyrenees. Bulletin de la Société géologique de 920 France 183(5):443-459.

921

922 Cochran, J.R., and Karner, G.D. (2007). Constraints on the deformation and rupturing of 923 continental lithosphere of the Red Sea: The transition from rifting to drifting. In Karner, G. D., 924 Manatschal, G., Pinheiro, L. M., editors, Imaging, Mapping and Modelling Continental 925 Lithosphere Extension and Breakup. Geological Society, London, Special Publications, $926 \quad 282: 265-289$.

927

928 Comas, M. C., García-Dueñas, V., and Jurado, M. (1992). Neogene tectonic evolution of the 929 Alboran Sea from MCS data. Geo-Marine Letters, 12(2-3):157-164.

930

931 Comas, M. C., Platt, J. P., Soto, J. I., and Watts, A. B. (1999). The origin and tectonic history 932 of the Alboran basin: Insights from LEG 161 results. In Zahn, R., Comas, M. C. and Klaus, A., 933 editors, Proceedings of the Ocean Drilling Program, Scientific Results:555-580.

934

935 Contrucci, I., Matias, L., Moulin, M., Geli, L., Klingelhofer, F., Nouze, H., Aslanian, D., 936 Olivet, J.L., Rehault, J.P., and Sibuet, J.C. (2004). Deep structure of theWest African 937 continental margin (Congo, Zaire, Angola), between $5^{\circ} \mathrm{S}$ and $8^{\circ} \mathrm{S}$, from reflection/refraction 938 seismics and gravity data. Geophysical Journal International, 158:529-553.

940 Crespo-Blanc, A. and Campos, J. (2001). Structure and kinematics of the south iberian 941 paleomargin and its relationship with the Flysch Trough Units: extensional tectonics within 
942 the Gibraltar arc fold-and-thrust belt (Western Betics). Journal of Structural Geology,

943 23(10):1615-1630.

944

945 Crespo-Blanc, A. and Frizon de Lamotte, D. (2006). Structural evolution of the external zones

946 derived from the Flysch Trough and the south iberian and maghrebian paleomargins around

947 the Gibraltar arc: a comparative study. Bulletin de la Societé Géologique de France, 948 177(5):267-282.

949

950

Cruz San Julían, J. (1990). Sheet Teba, 1037. Geological map scale 1:50000, Instituto 951 Geológico y Minero de España, Madrid.

952

953 Davies, G. R., Nixon, P. H., Pearson, D. G., and Obata, M. (1993). Tectonic implications of 954 graphitized diamonds from the ronda, peridotite massif, southern Spain. Geology, 21(5):471955474.

956

957 Davis, M. and Kusznir, N. (2004). Depth-dependent lithospheric stretching at rifted 958 continental margins. Proceedings of NSF Rifted Margins Theoretical Institute, 136:1-92.

959

960 Del Olmo Sanz, A., Moreno Serrano, F., Campos Fernández, J., Estévez, A., García-Dueñas, 961 V., García-Rossell, L., Martín-Algarra, A., Orozco Fernández, M., and Sanz de Galdeano, C. 962 (1990). Sheet Ronda, 1051. Geological map scale 1:50000, Instituto Geológico y Minero de 963 España, Madrid.

964

965 Didon, J., Durand-Delga, M., and Kornprobst, J. (1973). Homologies géologiques entre les 966 deux rives du détroit de Gibraltar. Bulletin de la Societé Géologique de France, 15(2):77-105. 
968 Doblas, M. and Oyarzun, R. (1989). Neogene extensional collapse in the Western 969 Mediterranean (Betic-Rif alpine orogenic belt): Implications for the genesis of the Gibraltar 970 arc and magmatic activity. Geology, 17(5):430-433.

971

972 Duggen, S., Hoernle, K., van den Bogaard, P., and Harris, C. (2004). Magmatic evolution of 973 the Alboran region: The role of subduction in forming the Western Mediterranean and 974 causing the Messinian salinity crisis. Earth and Planetary Science Letters, 218(1-2):91-108.

975

976 Esteban, J. J., Cuevas, J., Vegas, N., and Tubía, J. M. (2008). Deformation and kinematics in 977 a melt-bearing shear zone from the Western Betic Cordilleras (southern Spain). Journal of 978 Structural Geology, 30(3):380-393.

979

980 Esteban, J. J., Sánchez-Rodríguez, L., Seward, D., Cuevas, J., and Tubía, J. M. (2004). The 981 late thermal history of the Ronda area, southern Spain. Tectonophysics, 389(1-2):81-92.

982

983 Esteban, J.J., Cuevas, J., Tubía, J., Sergeev, S., and Larionov, A. (2011). A revised 984 Aquitanian age for the emplacement of the Ronda Peridotites (Betic Cordilleras, southern 985 Spain). Geol. Mag., 148(1):183-187.

986

987 Esteban, J. J., Tubía, J. M., Cuevas, J., Seward, D., Larionov, A., Sergeev, S., and Navarro988 Vilá, F. (2013). Insights into extensional events in the Betic Cordilleras, southern Spain: New 989 fission-track and U-Pb SHRIMP analyses. Tectonophysics, 603:179-188.

990

991 Faccenna, C., Piromallo, C., Crespo Blanc, A., Jolivet, L., and Rossetti, F. (2004). Lateral 
992 slab deformation and the origin of the arcs of the western Mediterranean. Tectonics,

993 23:TC1012.

994

995 Feinberg, H., Saddiqi, O., and Michard, A. (1996). New constraints on the bending of the 996 Gibraltar arc from paleomagnetism of the Ronda peridotite (Betic Cordilleras, Spain). In 997 Morris A., T. D., editor, Paleomagnetism and Tectonics of the Mediterranean Region, volume 998105 of Geol. Soc. Lond. Spec. Pubs, The Geological Society, London:43-52.

999

1000 Fernández-Fernández, E.M., Jabaloy-Sánchez, A., Nieto, F., González-Lodeiro, F. (2007). 1001 Structure of the Maláguide Complex near Vélez Rubio (Eastern Betic Cordillera, SE Spain). 1002 Tectonics, 26:TC4008.

1003

1004 Fernández, M., Berástegui, X., Puig, C., García-Castellanos, D., Jurado, M. J., Torné, M., and 1005 Banks, C. (1998). Geophysical and geological constraints on the evolution of the 1006 Guadalquivir foreland basin, Spain. Geological Society, London, Special Publications, 1007 134(1):29-48.

1008

1009 Flinch J.F. (1993). Tectonic evolution of the Gibraltar Arc. PhD thesis, Rice University, 1010 Houston, Texas.

1012 Frasca, G., Gueydan, F., and Brun, J. P. (2015). Structural record of Lower Miocene 1013 westward Alboran Domain motion in the Western Betics (southern Spain). Tectonophysics, $1014 \quad 657: 1-20$

1015

1016 Frets, E. C., Tommasi, A., Garrido, C. J., Vauchez, A., Mainprice, D., Targuisti, K., and Amri, 
I. (2014). The Beni-Bousera peridotite (Rif belt, Morocco): an oblique-slip low-angle shear

1018 zone thinning the subcontinental mantle lithosphere. Journal of Petrology, 55(2):283-313.

1019

1020 Frizon de Lamotte, D. F., Leturmy, P., Missenard, Y., Khomsi, S., Ruiz, G., Saddiqi, O.,

1021 Guillocheau, F., and Michard, A. (2009). Mesozoic and cenozoic vertical movements in the 1022 atlas system (Algeria, Morocco, Tunisia): An overview. Tectonophysics, 475(1):9-28.

1023

1024

Froitzheim, N., Pleuger, J., and Nagel, T.J. (2006). Extraction faults. Journal of Structural

Geology, 28:1388-1395.

1026

1027

1028

1029

1030

1031

1032

1033

1034

1035

1036

1037

1038

1039

1040

1041

García-Dueñas, V., Balanyá, J. C., and Martínez-Martínez, J. (1992). Miocene extensional detachments in the outcropping basement of the northern Alboran basin (Betics) and their tectonic implications. Geo-Marine Letters, 12:88-95.

Garrido, C. J. and Bodinier, J.-L. (1999). Diversity of mafic rocks in the Ronda Peridotite: Evidence for pervasive melt-rock reaction during heating of subcontinental lithosphere by upwelling asthenosphere. Journal of Petrology, 40(5): 729-754.

Garrido, C. J., Gueydan, F., Booth-Rea, G., Précigout, J., Hidas, K., Padrón-Navarta, J. A., and Marchesi, C. (2011). Garnet lherzolite and garnet-spinel mylonite in the Ronda peridotite: Vestiges of Oligocene backarc mantle lithospheric extension in the Western Mediterranean. Geology, 39(10):927-930.

Gueguen, E., Doglioni, C., and Fernández, M. (1998). On the post-25 Ma geodynamic evolution of the Western Mediterranean. Tectonophysics, 298(1-3):259-269. 
1043 Gueydan, F., Morency, C., and Brun, J.-P. (2008). Continental rifting as a function of 1044 lithosphere mantle strength. Tectonophysics, 460(1-4):83-93.

1046 Gueydan, F. and Précigout, J. (2014). Modes of continental rifting as a function of ductile 1047 strain localization in the lithospheric mantle. Tectonophysics, 612-613:18-25.

Gueydan, F., Précigout, J., and Montési, L. G. J. (2014). Strain weakening enables continental plate tectonics. Tectonophysics, 63:189-196.

1052 Gueydan, F., Pitra P., Afiri, A., Poujol, M., Essaifi, A., and Paquette, J.-L. (2015). Oligo1053 Miocene thinning of the Beni Bousera peridotites and their Variscan crustal host rocks, 1054 Internal Rif, Morocco. Tectonics, 34:1244-1268.

1055

1056 Gutscher, M.-A., Malod, J., Rehault, J.-P., Contrucci, I., Klingelhoefer, F., Mendes-Victor, L., 1057 and Spakman, W. (2002). Evidence for active subduction beneath Gibraltar. Geology, $1058 \quad 30: 1071-1074$.

1059

1060 Hidas, K., Booth-Rea, G., Garrido, C. J., Martínez-Martínez, J. M., Padrón-Navarta, J. A., 1061 Konc, Z., Giaconia, F., Frets, E., and Marchesi, C. (2013). Backarc basin inversion and 1062 subcontinental mantle emplacement in the crust: kilometre-scale folding and shearing at the 1063 base of the proto-Alborán lithospheric mantle (Betic Cordillera, southern Spain). Journal of 1064 the Geological Society, 170(1):47-55.

1065

1066 Hidas, K., Varas-Reus, M. I., Garrido, C. J., Marchesi, C., Acosta-Vigil, A., Padrón-Navarta, 
J. A., Targuisti, K., and Konc, Z. (2015). Hyperextension of continental to oceanic-like

1068 lithosphere: The record of late gabbros in the shallow subcontinental lithospheric mantle of 1069 the westernmost Mediterranean. Tectonophysics, 650:65-79.

1071 Huismans, R. S. Beaumont, C. (2011). Depth-dependent extension, two-stage breakup and 1072 cratonic underplating at rifted margins. Nature, 473:74-78.

1073

1074

Insua-Arévalo, J.M., Martínez-Díaz, J.J., García-Mayordomo, J., and Martín-González, F.

(2012). Active tectonics in the Malaga Basin: evidences from morphotectonic markers

(Western Betic Cordillera, Spain). Journal of Iberian Geology, 38(1):175-190.

Iribarren, L., Vergés, J., and Fernández, M. (2009). Sediment supply from the Betic-Rif orogen to basins through Neogene. Tectonophysics, 475(1):68-84.

Johanesen, K. E. and Platt, J. P. (2015). Rheology, microstructure, and fabric in a large scale mantle shear zone, Ronda Peridotite, Southern Spain. Journal of Structural Geology, 73:1-17.

Johanesen, K., Platt, J. P., Kaplan, M. S., and Ianno, A. J. (2014). A revised thermal history of Planetary Science Letters, 393:187-199.

1088 Kornprobst, J. (1976). Signification structurale des péridotites dans l'orogéne Bético-Rifain: arguments tirés de l'étude des détritus observés dans les sédiments Paléozoïque. Bulletin de la Societé Géologique de France, 3:607-618. 
Lavier, L. L. and Manatschal, G. (2006). A mechanism to thin the continental lithosphere at

1093 magma-poor margins. Nature, 440(7082):324-328.

1094

1095

Lenoir, X., Garrido, C.J., Bodinier, J.L., Dautria, J.M., and Gervilla, F. (2001). The

recrystallization front of the Ronda peridotite: Evidence for melting and thermal erosion of

1097 subcontinental lithospheric mantle beneath the Alboran basin: Journal of Petrology, 42:141-

1098158.

1099

1100 Lister, G., Etheridge, M., and Symonds, P. (1986). Detachment faulting and the evolution of 1101 passive continental margins. Geology, 14(3):246-250.

1102

1103 Lonergan, L. and White, N. (1997). Origin of the Betic-Rif mountain belt. Tectonics, 16:5041104522.

1105

López-Garrido, A. C. and Sanz de Galdeano, C. (1999). Neogene sedimentation and tectoniceustatic control of the Malaga basin, south Spain. Journal of Petroleum Geology, 22(1):81-96.

Manatschal, G. (2004). New models for evolution of magma-poor rifted margins based on a reviewof data and concepts from West Iberia and the Alps. International Journal of Earth Sciences, 93:432-466.

1113 Manatschal, G., Froitzheim, N., Rubenach, M., and Turrin, B. (2001). The role of detachment 1114 faulting in the formation of an ocean-continent transition: insights from the Iberia abyssal 1115 plain. Geological Society, London, Special Publications, 187(1):405-428. 
1117 Marchesi, C., Garrido, C. J., Bosch, D., Bodinier, J.-L., Hidas, K., Padrón-Navarta, J.A., and

1118 Gervilla, F. (2012). A late Oligocene suprasubduction setting in the westernmost

1119 Mediterranean revealed by intrusive pyroxenite dikes in the Ronda Peridotite (southern 1120 Spain): The Journal of Geology, 120(2):237-247.

1122 Martín-Algarra, A. (1987). Evolución geológica alpina del contacto entre las Zonas Internas y 1123 las Zonas Externas de la Cordillera Bética. PhD thesis, Universidad de Granada.

Mazzoli, S. and Martín-Algarra, A. (2011). Deformation partitioning during transpressional emplacement of a 'mantle extrusion wedge': the Ronda peridotites, Western Betic Cordillera, 1127 Spain. Journal of the Geological Society of London, 168:373-382.

Mazzoli, S., Martín-Algarra, A., Reddy, S., Sánchez-Vizcaíno, V. L., Fedele, L., and Noviello,

A. (2013). The evolution of the footwall to the ronda subcontinental mantle peridotites: insights from the Nieves Unit (Western Betic Cordillera). Journal of the Geological Society of 1132 London, 170:385-402.

1134 Mohn G., Manatschal G., Müntener O., Beltrando M., Masini E. (2010). Unravelling The 1135 Interaction Between Tectonic And Sedimentary Processes During Lithospheric Thinning In 1136 The Alpine Tethys Margins. Int. J. Earth Sci., 99:75-101.

1138 Mohn, G., Manatschal, G., Beltrando, M., Masini, E., Kusznir, N. (2012). Necking of 1139 continental crust in magma-poor rifted margins: evidence from the fossil Alpine Tethys 1140 margins. Tectonics, 31:TC2961. 
1142 Monié, P., Torres-Roldán, R., and García-Casco, A. (1994). Cooling and exhumation of the

1143 Western Betic Cordillera, 40Ar/39Ar thermochronological constraints on a collapsed terrane.

1144 Tectonophysics, 238(1-4):353-379.

1145

1146 Montel, J.-M., Kornprobst, J., and Vielzeuf, D. (2000). Preservation of old U-Th-Pb ages in 1147 shielded monazite: example from the Beni-Bousera hercynian kinzigites (Morocco). Journal 1148 of Metamorphic Geology, 18(3):335-342.

1150 Moulin M., Aslanian D., Olivet J.L., Klingelhoefer F., Nouzé H., Rehault J.P., Unterneuhr P. 1151 (2005). Geological constraints on the evolution of the angolan margin based on reflection and 1152 refraction seismic data (Zaïango Project). Geophys. J. Int., 162:793-810.

1153

1154 Nagel, T. J. and Buck, W. R. (2004). Symmetric alternative to asymmetric rifting models. 1155 Geology, 32(11):937-940.

1157 Navarro-Vilá, F. and Tubía, J. (1983). Essai d'une nouvelle différenciation des nappes 1158 Alpujarrídes dans le secteur occidental des Cordilléres Bétiques (Andalousie, Espagne). C. R. 1159 Acad. Sci. Paris, 296:111-114.

1160

1161 Negro, F., Beyssac, O., Goffé, B., Saddiqi, O., and Bouybaouéne, M. L. (2006). Thermal 1162 structure of the Alboran Domain in the Rif (northern Morocco) and the Western Betics 1163 (southern Spain). Constraints from Raman spectroscopy of carbonaceous material. Journal of 1164 Metamorphic Geology, 24 (4):309-327.

1165

1166 Obata, M. (1980). The Ronda peridotite: garnet-, spinel-, and plagioclase-lherzolite facies and 
1167 the P-T trajectories of a high-temprature mantle intrusion. Journal of Petrology, 21(3):533-

1168572.

1169

1170 Osmundsen, P. T., and Ebbing, J. (2008). Styles of extension offshore mid-Norway and

1171 implications for mechanisms of crustal thinning at passive margins. Tectonics, 27:TC6016.

1173 Palomeras, I., Thurner, S., Levander, A., Liu, K., Villasenor, A., Carbonell, R., and Harnafi, 1174 M. (2014). Finite-frequency Rayleigh wave tomography of the western Mediterranean: 1175 Mapping its lithospheric structure. Geochemistry, Geophysics, Geosystems, 15(1):140-160.

1177 Pearson, D.G., Davies, G.R., Nixon, P.H., and Milledge, H.J. (1989). Graphitized diamonds 1178 from a peridotite massif in Morocco and implications for anomalous diamond occurrences: 1179 Nature, 335:60-63.

Pearson, D.G. and Nowell, G.M. (2004). Re-Os and Lu-Hf isotope constraints on the origin 1182 and age of pyroxenites from the Beni Bousera peridotite massif implications for mixed 1183 peridotite pyroxenite mantle sources. Journal of Petrology, 45: 439-455.

1185 Péron-Pinvidic, G. and Manatschal, G. (2009). The Final Rifting Evolution At Deep Magma1186 Poor Passive Margins From Iberia-Newfoundland: A New Point Of View. Int. J. Earth Sci., $118798: 1581-1597$.

1189 Péron-Pinvidic, G., Manatschal, G., Minshull, T. A. and Sawyer, D. S. (2007). 1190 Tectonosedimentary evolution of the deep Iberia-Newfoundland margins: Evidence for a 1191 complex breakup history. Tectonics, 26:1-29. 
1193 Peyre, Y. (1974). Géologie d'Antequera et de la région Cordillères Bétiques (Espagne). PhD 1194 thesis, University of Paris, France. 528 pp.

1196 Platt, J. P., Allerton, S., Kirker, A., and Platzman, E. (1995). Origin of the western subbetic 1197 arc (south Spain): palaeomagnetic and structural evidence. Journal of Structural Geology, 1198 17(6):765-775.

1199

Platt, J. P., Argles, T., Carter, A., Kelley, S., Whitehouse, M., and Lonergan, L. (2003a).

Exhumation of the Ronda peridotite and its crustal envelope: constraints from thermal modelling of a P-T-time array. Journal of the Geological Society, 160(5):655-676.

1203

1204

Platt, J. P., Behr, W. M., Johanesen, K., and Williams, J. R. (2013). The Betic-Rif arc and its orogenic hinterland: A review. Annual Review of Earth and Planetary Sciences, 41(1):313357.

1207

Platt, J. P., and Whitehouse, M. (1999). Early Miocene high-temperature metamorphism and rapid exhumation in the Betic Cordillera (Spain): evidence from U-Pb zircon ages. Earth and Planetary Science Letters, 171(4):591-605.

1212 Platt, J. P., Whitehouse, M., Kelley, S., Carter, A., and Hollick, L. (2003b). Simultaneous 1213 extensional exhumation across the Alboran Basin: implications for the causes of late orogenic extension. Geology, 31(3):251-254. 
1217 in the subcontinental mantle - a ductile alternative to the brittle mantle. Tectonophysics, $1218 \quad 445(3-4): 318-336$.

Précigout, J., Gueydan, F., Garrido, C. J., Cogné, N., and Booth-Rea, G. (2013). Deformation

1221 and exhumation of the Ronda peridotite (Spain). Tectonics, 32(4):1011-1025.

1223 Ranero, C., and Pérez-Gussinyé, M. (2010). Sequential faulting explains the asymmetry and extension discrepancy of conjugate margins: Nature, 468(7321): 294-299.

Reston, T.J. (2007). The extension discrepancy at North Atlantic non-volcanic rifted margins: depth-dependent stretching or unrecognised faulting?: Geology, 35 :367-370.

Rosenbaum, G. and Lister, G. S. (2004). Formation of arcuate orogenic belts in the western

Royden, L. H. (1993). Evolution of retreating subduction boundaries formed during continental collision. Tectonics, 12:629-638.

Ruiz Cruz, M. D. and Sanz de Galdeano, C. (2014). Garnet variety and zircon ages in UHP

1237 Spain): evidence for a pre-alpine emplacement of the Ronda Peridotites. International 1238 Geology Review, 56(7):845-868.

1240 Sánchez-Gómez, M., Azañón, J. M., García-Dueñas, V., and Soto, J. I. (1999). Correlation 1241 between metamorphic rocks recovered from site 976 and the Alpujárride rocks of the Western 
1242 Betics. In Zahn, R., Comas, M. C. and Klaus, A., editors, Proceedings of the Ocean Drilling

1243 Program, Scientific Results:307-317.

1244

1245 Sánchez-Gómez, M., Balanyá, J. C., García-Dueñas, V., and Azañón, J. M. (2002).

1246 Intracrustal tectonic evolution of large lithosphere mantle slabs in the western end of the

1247 Mediterranean orogen (Gibraltar arc). Journal of the Virtual Explorer, 8:23-34.

1248

1249 Sánchez-Navas, A., García-Casco, A. and Martín-Algarra, A. (2014). Pre-Alpine discordant 1250 granitic dikes in the metamorphic core of the Betic Cordillera: tectonic implications. Terra 1251 Nova, 26(6):477-486.

1252

1253 Sánchez-Rodríguez, L. and Gebauer, D. (2000). Mesozoic formation of pyroxenites and 1254 gabbros in the Ronda area (southern Spain), followed by Early Miocene subduction 1255 metamorphism and emplacement into the middle crust: U-Pb sensitive high-resolution ion 1256 microprobe dating of zircon. Tectonophysics, 316(1-2):19-44.

1258 Sanz de Galdeano, C., Serrano, F., López-Garrido, A. C. and Martín-Pérez, J. A. (1993). 1259 Paleogeography of the Late Aquitanian-Early Burdigalian Basin in the Western Betic internal 1260 zone. Geobios, 26(1):43-55.

1261

1262 Serrano, F., Guerra-Merchán, A., Kadiri, K. E., Sanz de Galdeano, C., López-Garrido, A. C., 1263 Martín-Martín, M., and Hlila, R. (2007). Tectono-sedimentary setting of the Oligocene-Early 1264 Miocene deposits on the Betic-Rifian Internal Zone (Spain and Morocco). Geobios, 1265 40(2):191-205. 
1267 Soto, J. I. and Gervilla, F. (1991). Los macizos ultramáficos de Sierra de las Aguas y Sierra

1268 de la Robla como una ventana extensional (Béticas occidentales). Geogaceta, 9, 21-23.

1270 Soustelle, V., Tommasi, A., Bodinier, J.L., Garrido, C.J., Vauchez, A. (2009). Deformation 1271 and reactive melt transport in the mantle lithosphere above a large-scale partial melting 1272 domain: the Ronda Peridotite Massif, southern Spain. J. Petrol. 50:1235-1266.

1273

1274 Suades, E. and Crespo-Blanc, A. (2013). Gravitational dismantling of the Miocene mountain

1275 front of the Gibraltar Arc system deduced from the analysis of an olistostromic complex. 1276 Geologica Acta, 11(2):215-229.

1278 Torres-Roldán, R. L. (1979). The tectonic subdivision of the betic zone (betic cordilleras, 1279 south- ern spain); its significance and one possible geotectonic scenario for the westernmost alpine belt. American Journal of Science, 279(1):19-51.

Torres-Roldán, R.L., Poli, G., Peccerillo, A. (1986). An Early Miocene arc-tholeiitic magmatic dike event from the Alboran Sea - Evidence for precollisional subduction and backarc crustal extension in the westernmost Mediterranean. Geologische Rundschau, 75:219-234.

Tubía, J., Cuevas, J., and Esteban, J. (2004). Tectonic evidence in the Ronda Peridotites, 1287 Spain, for mantle diapirism related to delamination. Geology, 32(11):941-944.

Tubía, J., Cuevas, J., and Esteban, J. (2013). Localization of deformation and kinematic shift during the hot emplacement of the ronda peridotites (Betic Cordilleras, southern Spain).

1291 Journal of Structural Geology, 50:148-160. 
1293 Tubía, J., Cuevas, J., and Ibarguchi, J. G. (1997). Sequential development of the metamorphic

1294

1295

1296

1297

1298

1299

1300

1301

1302

1303

1304

1305

1306

1307

1308

1309

1310

1311

1312

1313

1314 Van Hinsbergen, D. J. J., Vissers, R. L. M., and Spakman, W. (2014). Origin and 1315 consequences of Western Mediterranean subduction, rollback, and slab segmentation.

1316 Tectonics, 33(4):393-419. 
1318 Vergés, J. and Fernández, M. (2012). Tethys-Atlantic interaction along the Iberia-Africa plate

1321 Villasante-Marcos, V., Osete, M., Gervilla, F., and García-Dueñas, V. (2003). Palaeomagnetic 1322 study of the Ronda peridotites (Betic Cordillera, southern Spain). Tectonophysics, 1323 377(1):119-141.

Vissers, R. L. M., Platt, J. P., and van der Wal, D. (1995). Late orogenic extension of the

Betic Cordillera and the Alboran domain: A lithospheric view. Tectonics, 14:786-803.

Watts, A., Platt, J. P., and Buhl, P. (1993). Tectonic evolution of the Alboran sea basin. Basin Research, 5:153-177.

Whitehouse, M. and Platt, J. (2003). Dating high-grade metamorphism - constraints from rare-earth elements in zircon and garnet. Contributions to Mineralogy and Petrology, 145(1):61-74. continental margin at $40^{\circ} 30^{\prime} \mathrm{N}$ deduced from surface and deep-tow magnetic anomalies. 1337 Journal of Geophysical Research: Solid Earth, 100(B3):3789-3806. continental margins from rifting to seafloor spreading. Nature, 413:150-154. 
1342 Wilson, R. C. L., Manatschal, G. and Wise S. (2001). Rifting along non-volcanic passive

1343 margins: Stratigraphic and seismic evidence from the Mesozoic successions of the Alps and

1344 western Iberia. In R. C. L. Wilson, R. B. Whitmarsh, B. Taylor and N. Froitzheim, editors,

1345 Non-volcanic Rifting of Continental Margins: A Comparison of Evidence From Land and Sea.

1346 Geol. Soc. Spec. Publ., 187: 429-452.

1348 Wortel, M. J. R. and Spakman, W. (2000). Subduction and slab detachment in the 1349 Mediterranean-Carpathian region. Science, 209:1910-1917.

1351 Zindler, A., Staudigel, H., Hart, S.R., Endres, R., and Goldstein, S. (1983). Nd and Sm 1352 isotopic study of a mafic layer from Ronda ultramafic complex. Nature, 304:226-230.

Figure captions

Fig. 1. a) Tectonic map of the Western Betics with foliation trajectories (modified after Frasca et al. 2015) showing the main geological units: Ronda peridotites with plagioclase tectonites (dark green and pale green), lower, middle and upper crustal rocks above the peridotites (violet, dark brown and pale brown), crustal rocks below the peridotites (pale blue), lower Miocene Alozaina basin (beige) and

1361 Tortonian basins (pale yellow). Major tectonic contacts: Ronda Peridotites Thrust (RPT), Internal1362 External Zone Boundary (IEZB), crust-mantle extensional shear zone (white line). Top left inset: 1363 Location of the study area in the Betic-Rif belt with the location of the Ronda-Beni Bousera mantle 1364 bodies. Bottom right inset: synthetic vertical section of the lithological and tectonic units of the 1365 Western Betics. b) E-W trending cross-section; see location AA' in (a). 
the present day geometry of the trench and its hypothetical position at $30 \mathrm{Ma}$. (b) Rifting at the front of the subduction upper plate responsible for mantle exhumation. (c) Rift inversion and thrust emplacement of the Ronda Peridotites on top of the Iberian margin (modified after Précigout et al., 2013).

Fig. 3. (a) Structural map of the Carratraca peridotitic massives (synthetized after Chamón Cobos et al., 1972; Cano Medina and Ruiz Reig, 1990; Cruz San Julían, 1990; Del Olmo Sanz et al., 1990; Soto and Gervilla, 1991; Argles et al., 1999; Tubía et al., 2004 and Frasca et al., 2015). Green star: position of the sample (GFD7) collected for the ${ }^{40} \mathrm{Ar} /{ }^{39} \mathrm{Ar}$ dating. LGFZ: Los Grenadillos Fault Zone. (b) NS cross-section showing the geometry of the three blocks of Sierra Agua, Sierra de la Robla and Alozaina. See location in (a).

Fig. 4. Kinematics and age of high-angle normal faults. (a) Outcrop photograph of the Cerro Tajo fault that put in contact middle crust gneisses with serpentinized mantle rocks (b) Hand-specimen (GFD7) of the fault breccia sampled for ${ }^{40} \mathrm{Ar} /{ }^{39} \mathrm{Ar}$ dating (see location in Fig. 3.3a). White arrow: clast of the gneiss protolith containing only biotite. (c) Thin-section of sample GFD7 showing the formation of white mica pseudomorph after garnet. White arrow: very small white micas in the matrix (for details see "supplementary material", Fig. S3). (d and e) Stereoplots of fault surfaces (lower hemisphere projection on a Schmidt net; FSA software by Célérier, 2013: version 35.2) for Cerro Tajo fault and La Robla fault (e) (see location of the faults in Fig. 3.3a). Great circles: fault planes. Grey arrows: direction of motion on fault surfaces. (f) ${ }^{40} \mathrm{Ar} /{ }^{39} \mathrm{Ar}$ age spectrum for the mm-sized white micas extracted from the sample GFD7 (see method and analytical data in "supplementary material").

Fig. 5. Types of shear indicators used in crust and mantle rocks (a) Landscape view (from point 5a in Fig. 4) of the thinned lithosphere in the Sierra de Agua. Left inset: Summary of senses of shear at the different lithosphere levels (not to scale; green: mantle; violet: lower crust; dark brown: middle crust; light brown: upper crust) with location of photographs (see location in Fig. 4). (b) Top-to-W sense of shear in the mantle: deflection of a pyroxenite layer in the Grt-Sp mylonitic foliation. (c) Top-to-W 
1395

1396

1397

1398

1399

1400

1401

1402

1403

1404

1405

1406

1407

1408

1409

1410

1411

1412

1413

1414

1415

1416

1417

1418

1419

1420

1421

1422

sense of shear in the lower crust: melt in veins and in pressure shadows around a garnet porphyroclasts and C'-type shear-bands, locally enriched in melt, in molten granulites. (d) Top-to-W sense of shear in the middle crust: sigmoidal stretched leucosome. (e) Top-to-E sense of shear in the middle crust: sigmoidal stretched leucosome. (f) Eyed-type section of a sheath fold in the middle crust in the sillimanite gneisses. (g) Top-to-E sense of shear in the middle/upper crust: C'-type brittle-ductile shear bands in the andalusite schists.

Fig. 6. Map of mean senses of shear in the Carratraca area. Colors of geological units like in Fig. 3. Ductile shear in the mantle and lower crust (Violet arrows) and in the middle crust (Blue arrows). Brittle/ductile shear, mainly observed in the upper crust (Pale blue) (For the whole set of lineation and shear criteria see "supplementary material”, Fig. S1).

Fig. 7. Variations in crustal thickness. (a) Crustal thickness estimates in the Agua, La Robla and Alozaina blocks (green: mantle; violet: lower crust; dark brown: middle crust; light brown: upper crust) (See location in Fig. 3). (b) Estimates of the average thickness of the upper, middle and lower crust in the three blocks, made from local cross-sections that take into account variations in mean foliation dip.

Fig. 8. Low-angle normal fault (LANF) in the hyper-stretched portion of the rift (El Chenil area; see location in Fig. 6). (a) Landscape view of the El Chenil LANF. (b) Geological interpretation of the El Chenil fault zone (for detailed map and measurements see Fig. S2). (c) Photograph of ophicalcite.

(d) Fault gouge in the fault core zone with clasts of quartz-veins (Q), breccia (B) and gneiss (G). (e) C'-type shear bands (shown by blue arrows) in the upper crustal rocks indicating a top-to-E sense of shear. (f) Sedimentary breccia at the base of the Alozaina basin with clasts of upper crustal rocks.

Fig. 9. Summary of shear sense variations with depth and their implications in terms of horizontal displacement and rheology (strength profile), (a) at the onset of extension and (b) after a strong crustal thinning in the hyper-stretched portion of the lithosphere. 
1423

1424 Fig. 10. Three-stage conceptual model of lithosphere necking summarizing the progressive 1425 deformation recorded in the crust and mantle units of the Carratraca area. (a) Early stages controlled 1426 by the mid-crustal shear zone and the crust-mantle shear zone with opposite senses of shear. (b) 1427 Advanced stages cahracterized by localization of stretching at rift center leading to an extreme 1428 thinning of the ductile crust and omission of the lower crust. (c) Late stages of high-angle faulting 1429 cutting through the strongly attenuated crust and the cooling mantle.

1431 Fig. 11. Comparison of models of lithosphere necking up to mantle exhumation, which evolve either

1432 dominantly symmetrical (a and b) or asymmetrical (c and $\mathbf{d}$ ), with the lithosphere-scale deformation 1433 pattern documented in the western Betics (e and $\mathbf{f}$ ) (as summarized in Figs. 9 and 10). 


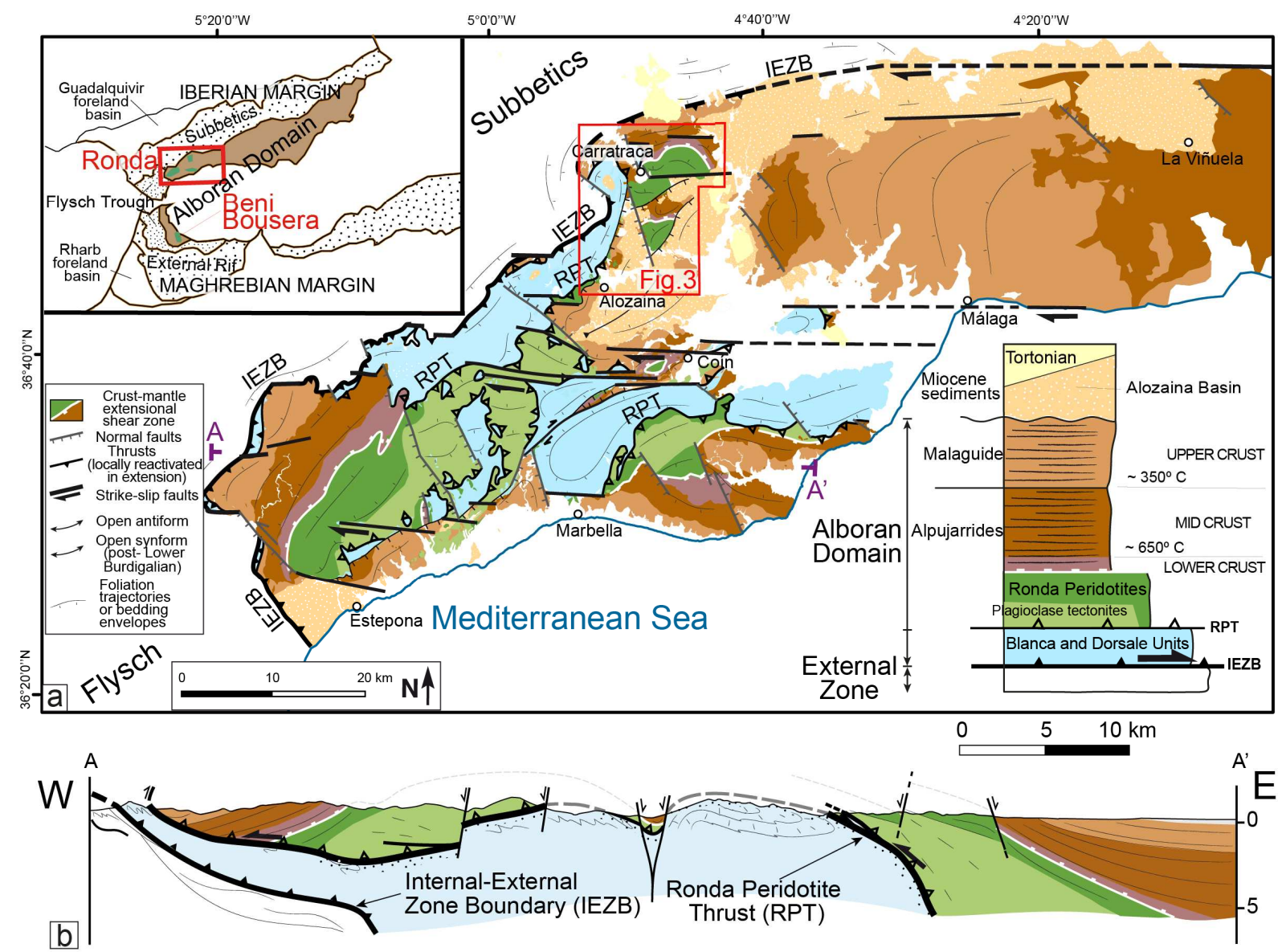



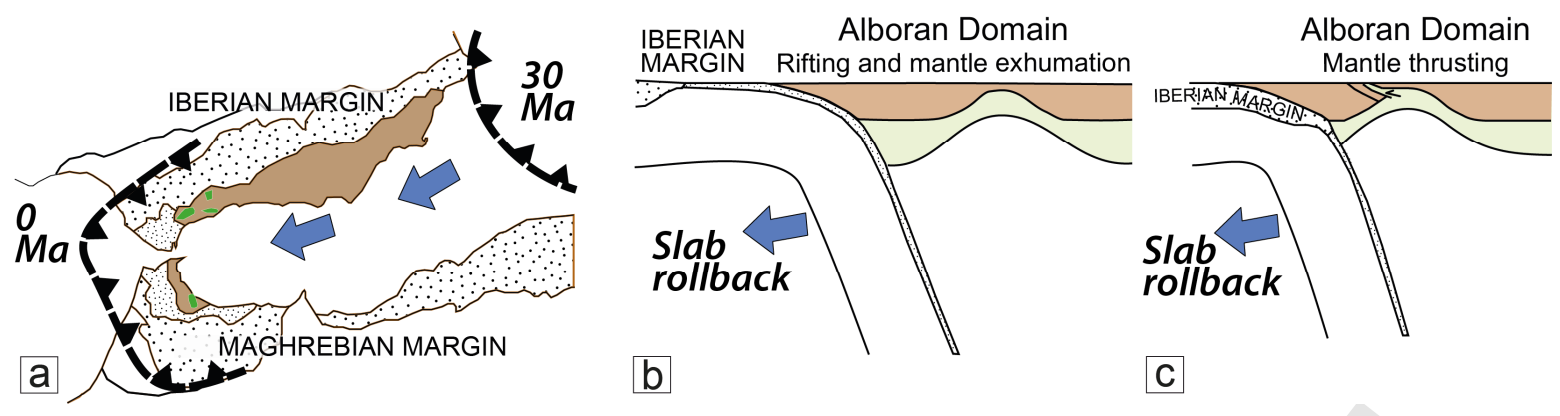

C 


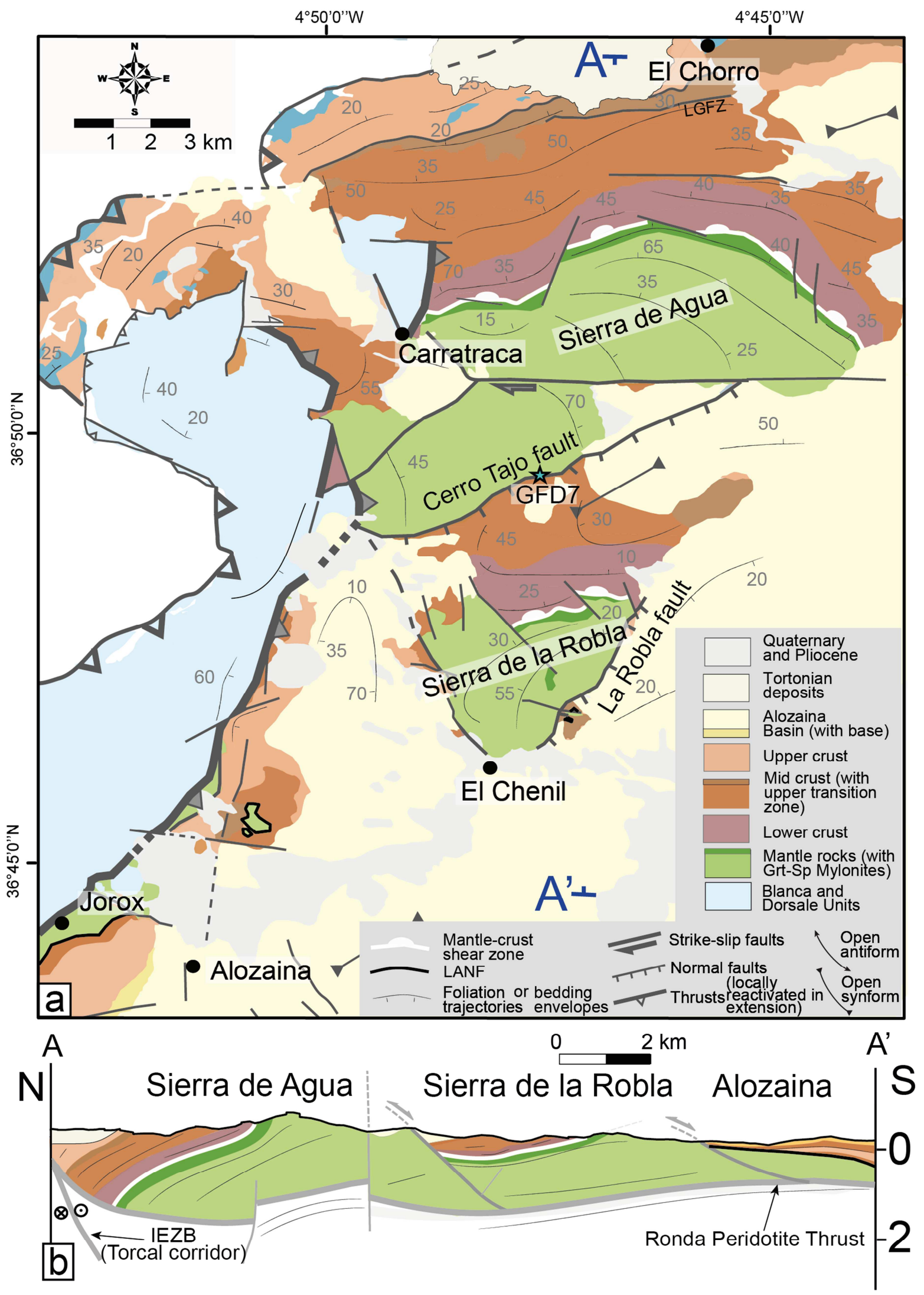



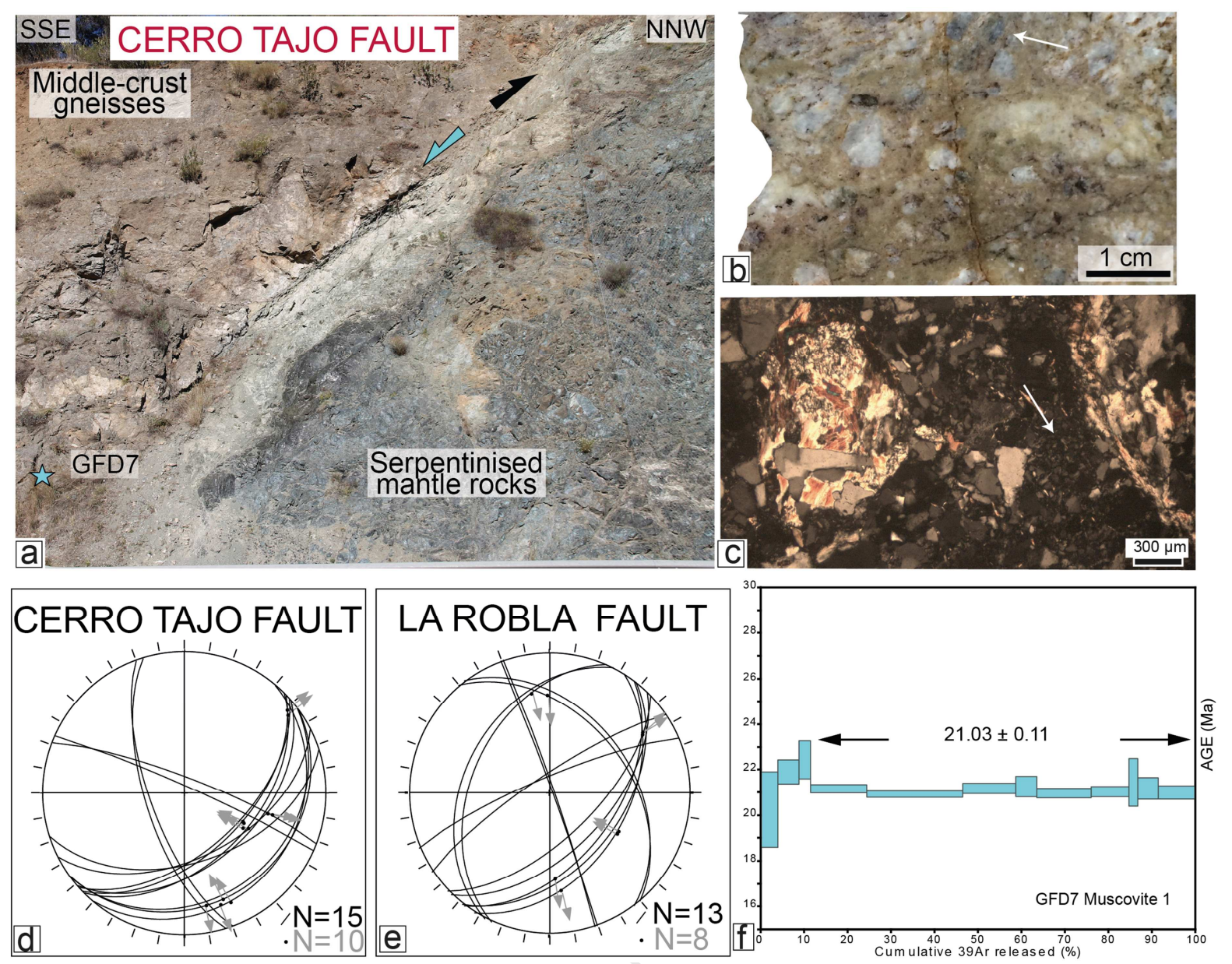


\section{ACCEPTED MANUSCRIPT}

E
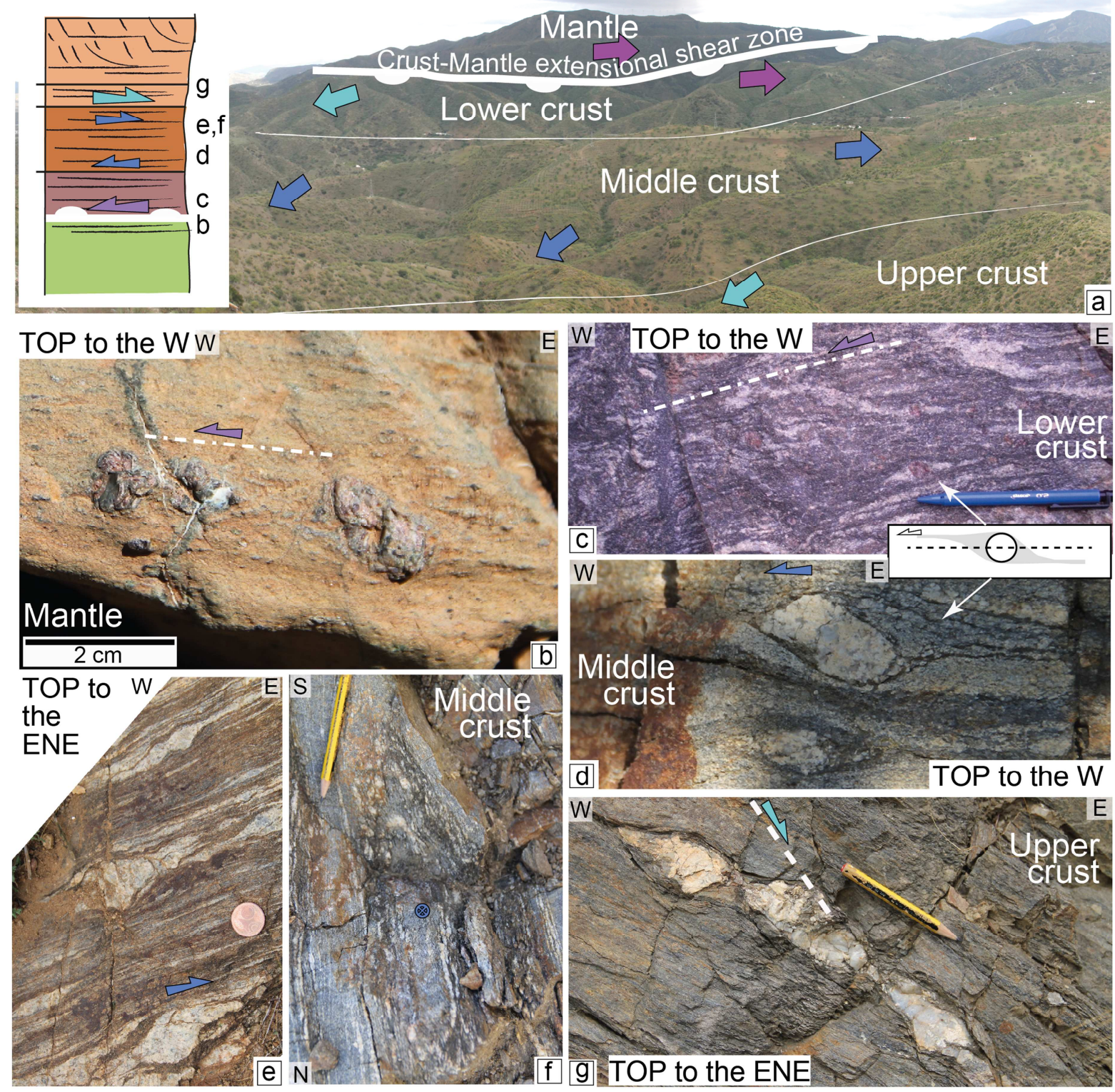


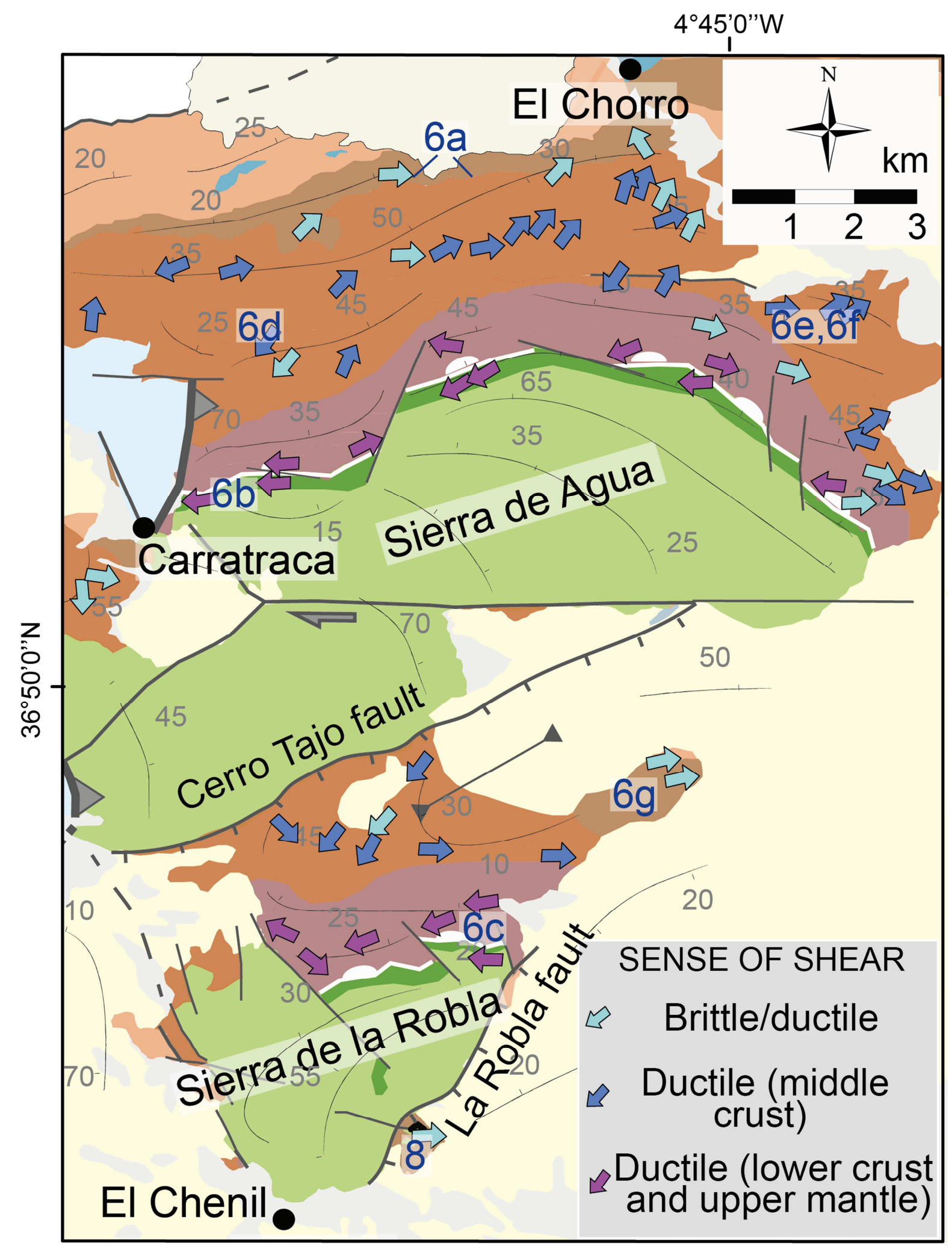



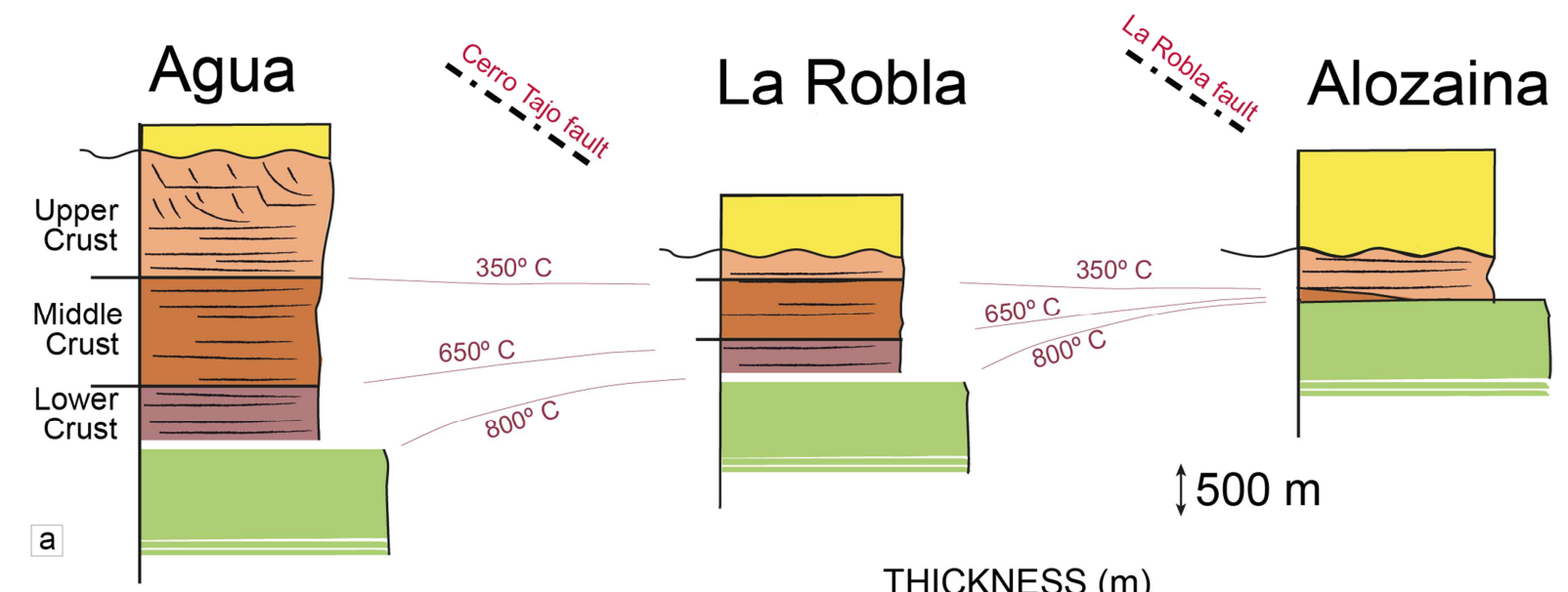

Agua

THICKNESS (m)

\begin{tabular}{|c|c|c|c|}
\hline & Agua & Robla & Alozaina \\
\hline $\begin{array}{l}\text { Upper Crust } \\
\text { totally or partly eroded }\end{array}$ & $>1270$ & 0 & $>480$ \\
\hline Middle Crust & 1510 & 950 & 50 \\
\hline Lower Crust & 560 & 370 & 20 \\
\hline Ductile crust & 1970 & 1070 & 70 \\
\hline
\end{tabular}



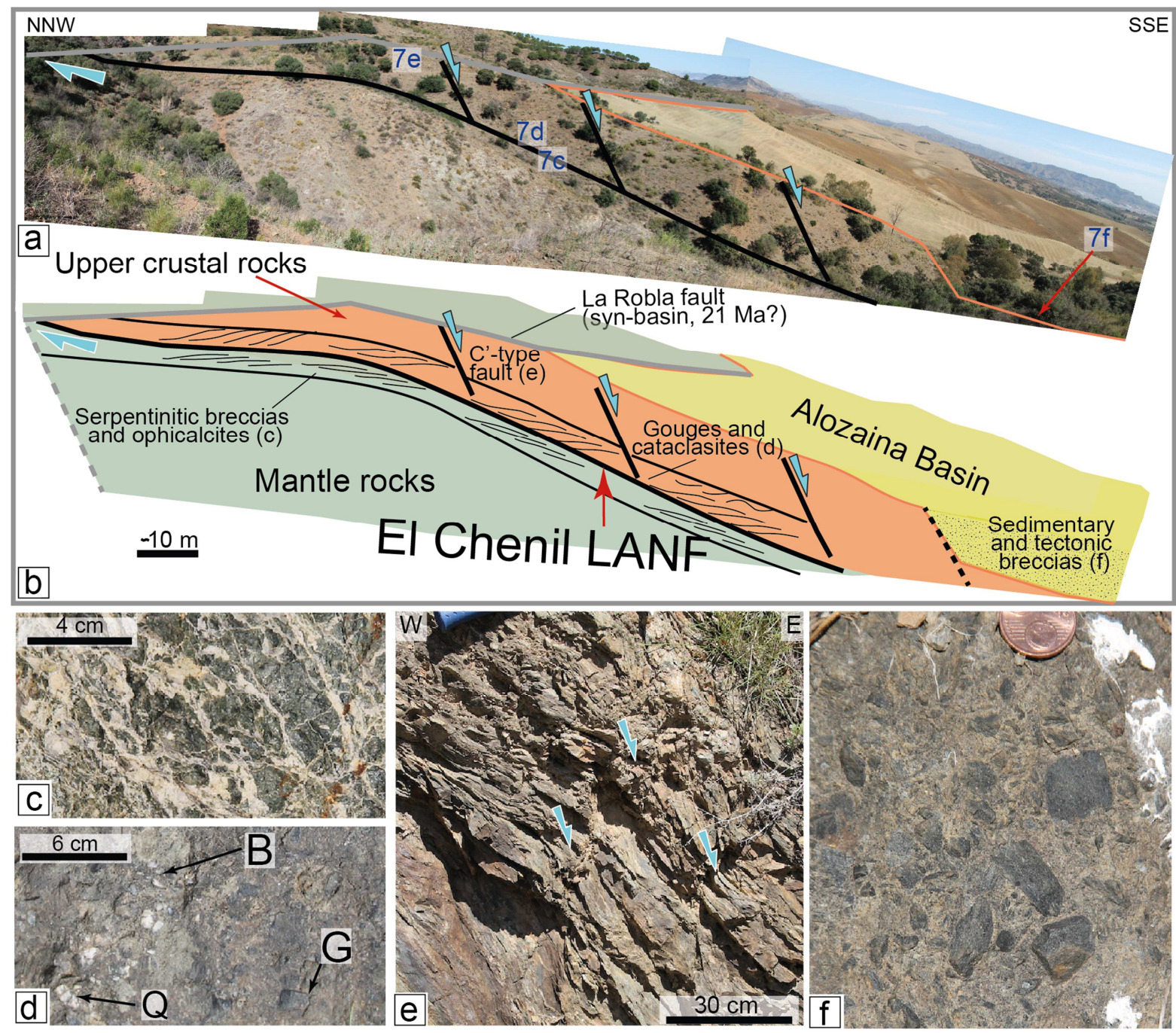


\section{a At the onset of extension}

Lithosphere layering

Displacement profile \& shear senses

Rheological implications

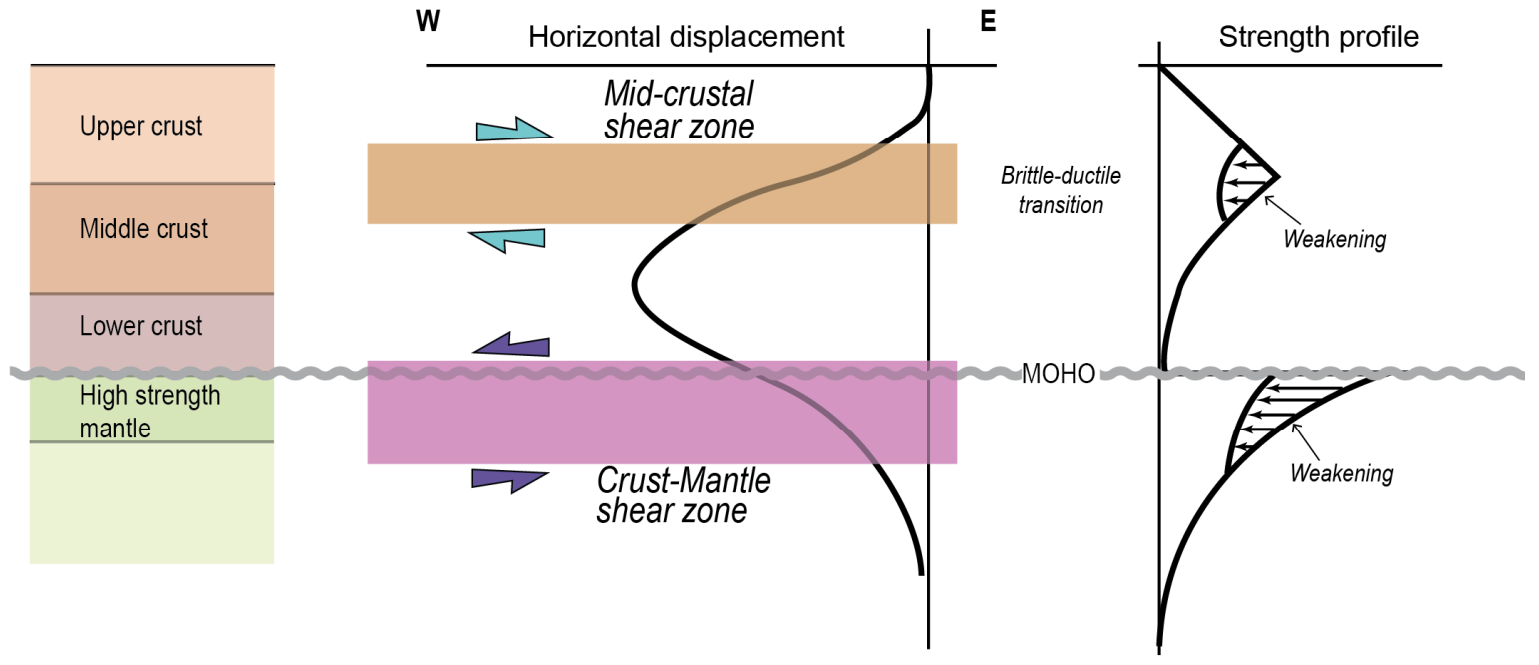

b After a significant amount of thinning (hyper-stretching)

Lithosphere layering

Displacement profile \& shear senses

Rheological implications

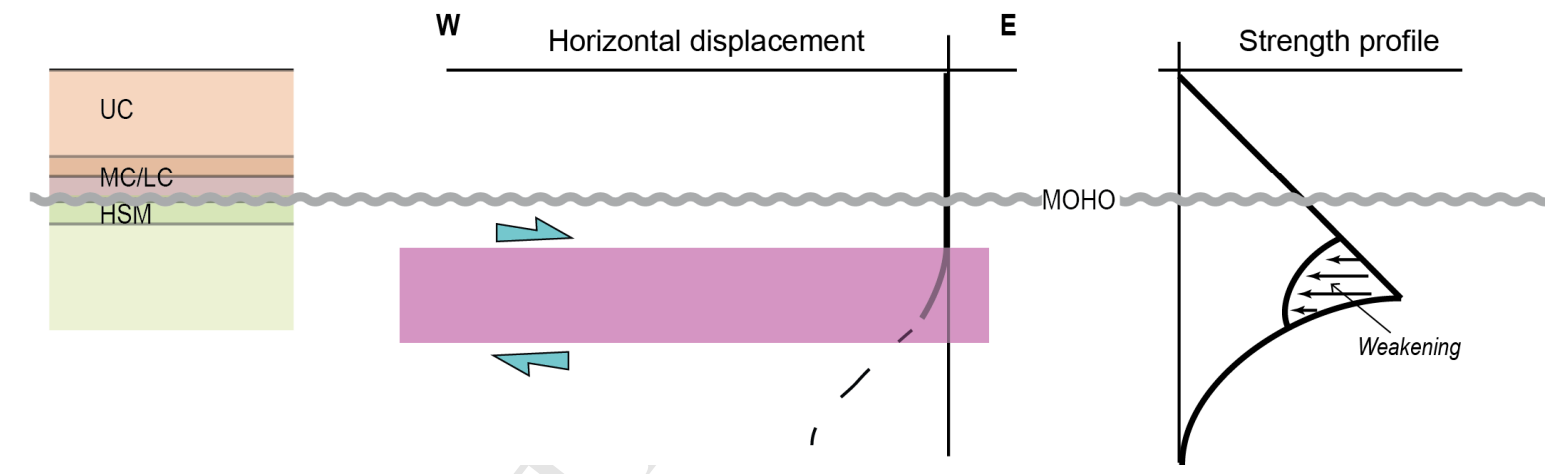


a 33-25 Ma; Early stages of lithosphere necking

Crust-mantle decoupling, crust heating by exhuming mantle

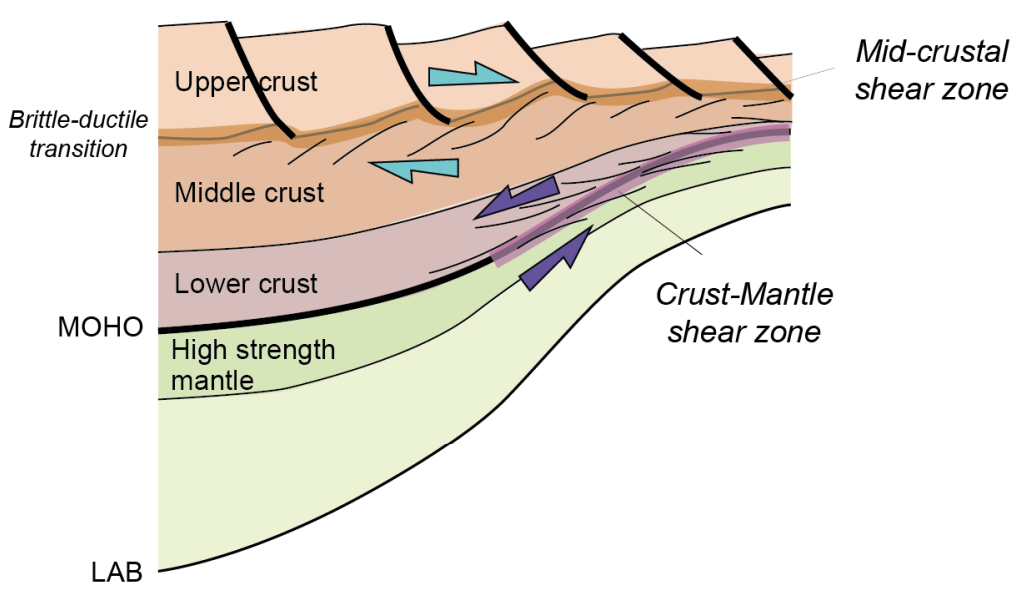

b 25-22 Ma; Advanced stages of lithosphere necking

Crust-mantle coupling, localisation (hyper-stretching), onset of cooling

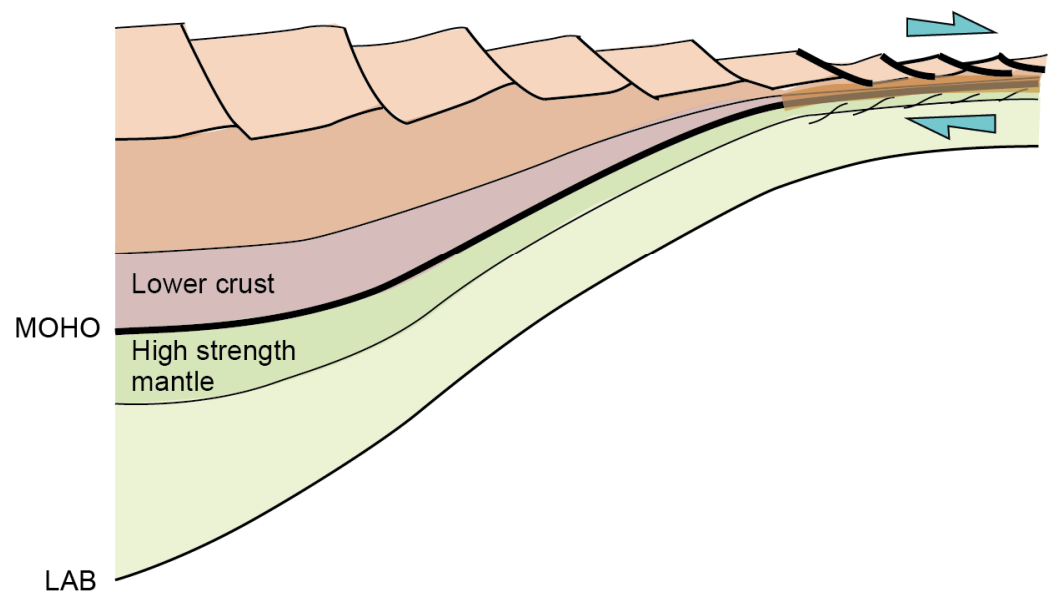

C 22-20 Ma; Late stages of lithosphere necking

Mantle faulting \& block tilting, cooling Agua Robla Alozaina

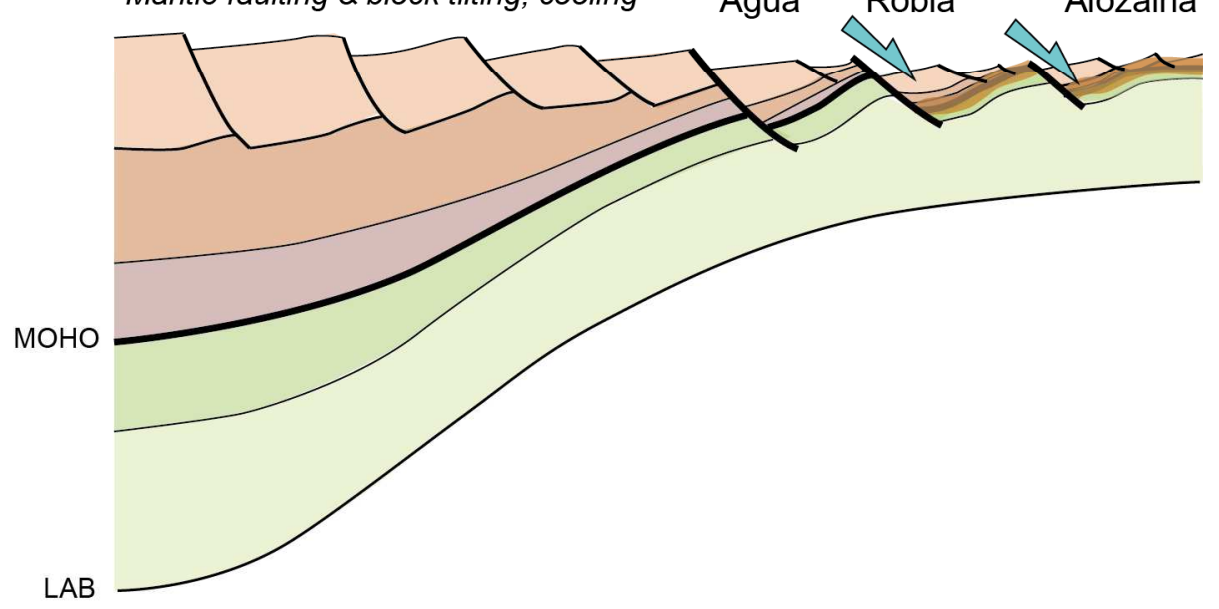




\section{First stages of necking}
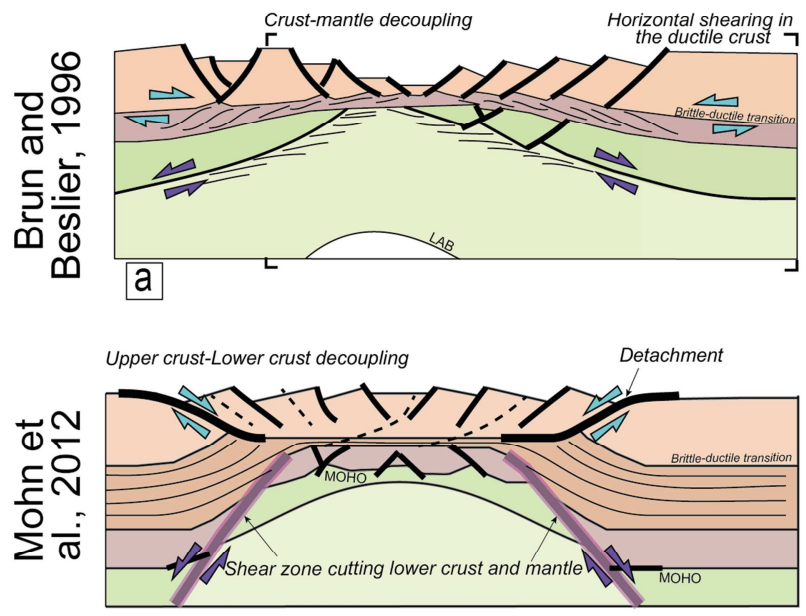

C

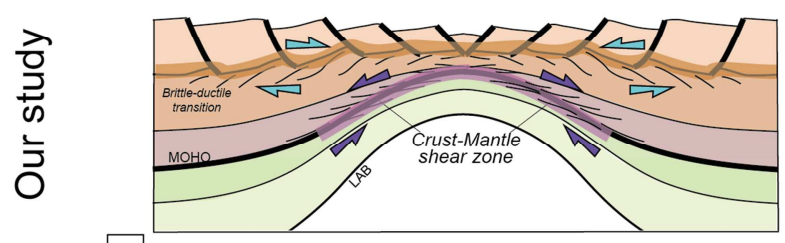

e
Upper crust
Middle crust
High strength mantle
Lower crust
Ductile mantle
Ductile shearing

\section{Mantle denudation}
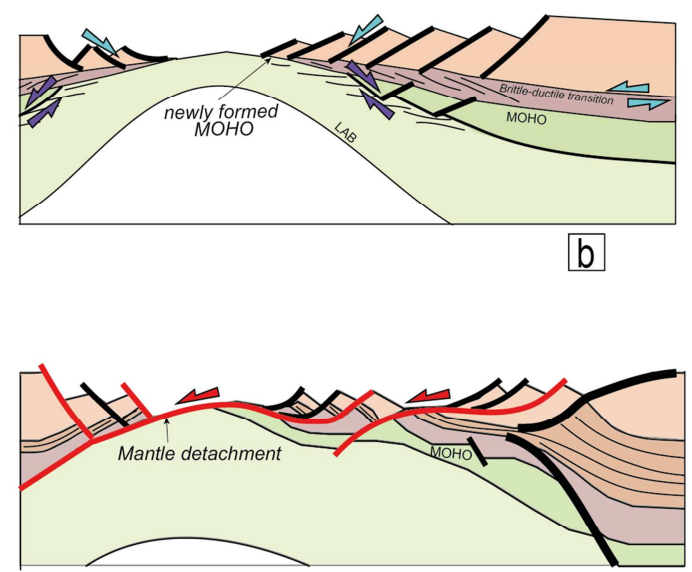

d
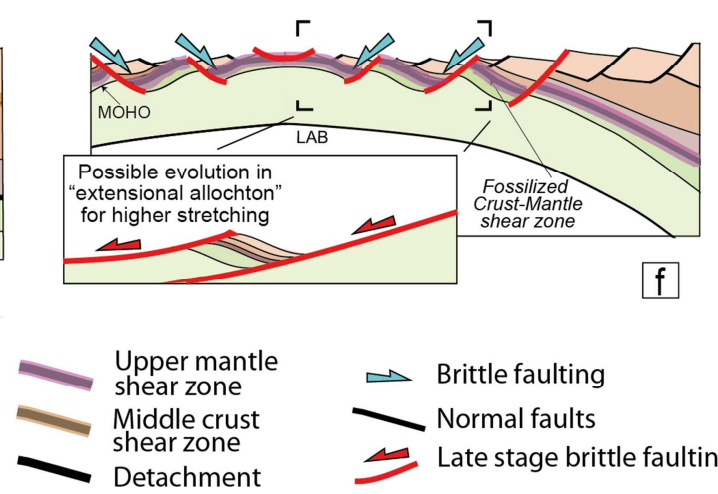

$\Longrightarrow$ Brittle faulting

Normal faults

$\Perp$ Late stage brittle faulting 


\section{Highlights}

- Western Betics (S Spain): exceptional exposures of thinned continental lithosphere

- Progressive lithosphere necking leads to crustal stretching values larger than $2000 \%$

- 1) mid-crustal and crust-mantle shear zones act with opposite senses of shear;

- 2) ductile crust disappears, and upper crust touches the subcontinental mantle

- 3) high-angle normal faults end mantle exhumation where stretching is localized. 